\title{
Discussion Paper \\ What Explains the Post-2011 Trends of Longer Maturities and Rising Default Rates on Auto Loans?
}

\section{Paul Calem}

Federal Reserve Bank of Philadelphia

Supervision, Regulation, and Credit Department

\section{Chellappan Ramasamy}

Federal Reserve Bank of Philadelphia

Supervision, Regulation, and Credit Department

\section{Jenna Wang}

Federal Reserve Bank of Philadelphia

Supervision, Regulation, and Credit Department
DP 20-02

April 2020

https://doi.org/10.21799/frbp.dp.2020.02 


\title{
What Explains the Post-2011 Trends of Longer Maturities and Rising Default Rates on Auto Loans?
}

\author{
Paul Calem, Chellappan Ramasamy, and Jenna Wang* \\ Supervision, Regulation, and Credit Department \\ Federal Reserve Bank of Philadelphia
}

April 2020

This paper quantifies relationships of long-term auto borrowing and auto-loan default to observable borrower characteristics and economic variables. We also quantify the residual components of the trends in long-term borrowing and delinquency not attributable to identifiable factors. Second, our paper provides new evidence on the relationship between longer-term borrowing and auto-loan default risk. We find that observable factors associated with the choice of a long loan term usually indicate an increased risk of default. We also find that the increasing share of long-term loans and the rising frequency of auto-loan default are mostly attributable by nonspecific, year-of-origination (fixed) effects rather than factors observable from our data or observable to lenders. Moreover, although borrowers opting for long loan terms are more likely to default in most comparisons, the increasing share of borrowers selecting a long loan term between 2011 and 2016 did not materially contribute to the rise in default rates. Overall, our analysis highlights the role of unobserved borrower characteristics in driving the recent trends in long-term borrowing and default.

Keywords: auto loans, longer maturities, default risk, observable characteristics, longer-term borrowings, origination vintages, household debt, student loans, credit cards, mortgage, HELOC, census tract, unemployment, auto lenders

JEL Classification Codes: D12, C23, G21

\footnotetext{
*Chellappan Ramasamy, Federal Reserve Bank of Philadelphia, Ten Independence Mall, Philadelphia, PA 19106-1574; email: chellappan.ramasamy@phil.frb.org. Paul Calem participated in this research in his prior position at the Federal Reserve Bank of Philadelphia; he is now a senior vice president at the Bank Policy Institute. We are grateful to Sharon Tang for sharing her method and code for imputing term-to-maturity, which we adapted for our empirical analysis.
}

Disclaimer: This Philadelphia Fed discussion paper represents preliminary research that is being circulated for discussion purposes. The views expressed in these papers are solely those of the authors and do not necessarily reflect the view of the Federal Reserve Bank of Philadelphia or the Federal Reserve System. Nothing in the text should be construed as an endorsement of any organization or its products and services. Any errors or omissions are the responsibility of the author. No statements here should be treated as legal advice. Philadelphia Fed discussion papers are free to download at https://www.philadelphiafed.org/consumer-finance-institute/publications. 


\section{Introduction}

As the U.S. economy recovered from the Great Recession and then continued to expand during 2011 through 2018, auto lending emerged as the fastest growing category of consumer debt. This increase in auto lending has been characterized by a surprising rise in the share of loans with long (more than 72 months) term-to-maturity and by an upward trend in frequency of default, despite the strong economy. The latter two trends have raised concerns about the potential adverse impact on lender and household exposure to financial risk. ${ }^{1}$

A key concern is the extent to which traditional risk indicators that lenders rely on to originate auto loans may have failed to anticipate the deterioration in repayment performance, leaving lenders less able to accurately assess borrower credit risk. A related concern is that, despite the improving economy, financial vulnerabilities have been increasing among some of the autoborrower population, contributing to both longer-term borrowing and rising delinquency.

This paper quantifies the relationships of long-term auto borrowing and auto-loan default to observable borrower characteristics and economic variables. In addition, we quantify the residual components of the trends in long-term borrowing and delinquency that are not attributable to identifiable factors. The paper thus offers a best effort assessment of the degree to which recent trends may reflect factors not captured by traditional credit risk measures.

Second, our paper provides new evidence on the relationship between longer-term borrowing and auto-loan default risk. Nearly all previous studies of auto-loan default address determinants of default or pricing of default risk without examining the relationship to term-tomaturity. ${ }^{2}$ Argyle, Nadauld, and Palmer (2019) present a compelling analysis of term-to-maturity

\footnotetext{
${ }^{1}$ See, for example, Auto Trends Magazine (2016) and Verma (2017).

2 Heitfield and Sabarwal (2004) find that by using asset-backed securities data default rates of subprime loans are more sensitive than prepayment rates to economic conditions. Agarwal, Ambrose, and Chomsisengphet (2008) examine auto-loan prepayment and default in relation to the type of auto, controlling for traditional credit risk measures. Adams, Einav, and Levin (2009) also focus on subprime lending using data from a large auto sales company. They find that default rates rise with loan size, implying a moral hazard and a rationale for lenders to impose loan caps, and they present evidence of effective risk-based pricing. Melzer and Schroeder (2015) examine the effects of usury restrictions on the auto-loan market and find that auto dealers compensate for credit risk through the markup on the vehicle sales price when usury restrictions are tight.
} 
selection for auto loans but do not directly address default risk. ${ }^{3}$ The selection of borrowers into default risk segments through choice of term-to-maturity has been considered in other lending contexts, most recently by Hertzberg, Liberman, and Paravisini (2018) in the context of unsecured consumer credit from an online lender. Our paper addresses both term-to-maturity selection and default risk for auto loans and identifies observable factors to which they share an association. ${ }^{4}$

To accomplish these goals, we construct and estimate logistic regression models for the choice of a long loan term and for default, using data from a nationally representative sample of consumer credit records merged with the economic characteristics of the borrower's county and Census tract of residence. We also conduct a separate, supplementary analysis of trends in auto lending using segment-level data collected quarterly by the Board of Governors of the Federal Reserve System from banking organizations subject to regulatory requirements of the Dodd-Frank Wall Street Reform and Consumer Protection Act, not previously used in prior studies of auto-loan default.

There are additional, distinguishing aspects of our analysis: We restrict attention to the choice among terms greater than 48 months in order to focus on term choice as a marginal decision by borrowers who are considering medium- versus long-term loans. This limits the complexity of the analysis, compared with modeling choice across the full range of possible loan terms. ${ }^{5}$ We also separately model individuals with and without a mortgage, as the latter group tends to be more creditworthy and often has access to backup liquidity via home equity credit.

We find that factors associated with the choice of a long loan term also usually indicate increased risk of default. Both outcomes, for instance, are associated with a higher credit card utilization rate, a lower per capita income, and a higher local area unemployment rate. However, although borrowers with a mortgage are characterized by a significantly lower likelihood of auto-

\footnotetext{
${ }^{3}$ Argyle, Nadauld, and Palmer (2019) study the relationship between monthly payment targeting by consumers and the terms of auto-loan contracts. They find that demand is more sensitive to term-to-maturity than to interest rate, consistent with consumers managing payment size when making debt decisions.

${ }^{4}$ Guo, Zhang, and Zhao (2018) find that auto loans with maturities beyond five years have higher delinquency rates than shorter-term loans over any given performance horizon, conditional on risk factors typically available during the underwriting process.

${ }^{5}$ It seems reasonable to assume that most borrowers are selecting a loan term based on the consideration of marginal benefits and costs. Typically, consumers who choose long-term loans do so to reduce their monthly payment to an affordable level. It seems unlikely that they could afford the relatively large monthly payment associated with a short-term loan without providing a much larger down payment or by purchasing a much lower-priced car, which they also may not be willing or able to do.
} 
loan delinquency, they are not less likely to use a long-term auto loan. This finding may reflect a greater willingness of lenders to offer longer-term loans to borrowers they perceive to have a lower credit risk.

We also find that the increasing share of long term loans and the rising frequency of autoloan default is chiefly attributable to nonspecific, year-of-origination (fixed) effects rather than factors observed from our data or observed by lenders. Although identifiable factors provide differentiation across borrowers, the likelihood of choosing a long loan term and the likelihood of default have been rising over time for all borrowers; we are unable to connect these trends to those factors. Moreover, although borrowers opting for long loan terms are more likely to default in most comparisons, the increasing share of borrowers selecting a long loan term between 2011 and 2016 did not materially contribute to the rise in default rates.

The paper is organized as follows. Section 2 describes the data sources for the study and the data preparation process, including exclusions applied to the data and imputation of the loan term. Section 3 examines trends in auto borrowing and default in the 2011-2018 period. Sections 4 and 5, respectively, develop the regression models and discuss the model estimation results and implications. Section 6 concludes.

\section{Data Sources and Preparation}

Our study relies mostly on two data sets derived from a nationally representative sample of individual consumer credit records: The Federal Reserve Bank of New York/Equifax Consumer Credit Panel (FRBNY Equifax CCP), and Equifax Auto Tradeline data. The FRBNY Equifax CCP is a panel data set with information derived from the credit reports of sampled consumers, aggregated to the individual overall or by account type and updated quarterly. The Equifax Auto Tradeline data provide additional, account-level information on up to four active auto loan or lease accounts for the subpopulation of primary consumers in the FRBNY Equifax CCP with auto loans or leases, updated semiannually. ${ }^{6}$

\footnotetext{
${ }^{6}$ The Equifax panel of primary individuals constitutes a 5 percent random sample of all individuals with a Social Security number and a credit record, totaling about 12 million records each quarter. The full Equifax panel also incorporates individuals residing in the same household; these secondary individuals are excluded from our sample. See Lee and van der Klaauw (2010) and Wardrip and Hunt (2013) for a more detailed description of the Equifax panel.
} 
The primary sample for our analysis consists of all auto accounts in the Equifax Auto Tradeline data having an origination date in the period January 2011-December 2018, which total around 13.1 million accounts. These data incorporate static, account-level attributes, including date open, original loan amount, required monthly payment, and lender type (bank, credit union, auto finance company, and "other"), and for some loans, the term-to-maturity. ${ }^{7}$ In addition, the data provide semiannual updates of dynamic variables, including the remaining principal balance and repayment status (days past due).

We drop leases from the sample because they are usually associated with terms of 48 months or shorter, an additional exclusion criterion to be adopted, as discussed next. The question of what drives the choice of an extended term is not a relevant issue for consumers seeking shorter-term credit, including leases. ${ }^{8}$

To these data, we append selected, borrower-level information from the FRBNY Equifax CCP for the quarter of origination of the auto loan. The appended FRBNY Equifax CCP data include the age (in months) of the oldest and newest accounts, the total number and outstanding balance by type of account, the overall utilization rate of credit card lines, and the Equifax Risk Score (Risk Score). The latter item is a consumer risk score such that higher risk scores indicate a lower risk of defaulting on a credit obligation. In addition, from the credit record data, we include the borrower's age and the state, county, and Census tract location of the borrower's mailing address. ${ }^{9}$

Next, we merge in the county unemployment rate (by state, county, and quarter) from Haver Analytics and the county House Price Index (HPI) from CoreLogic Solutions. Finally, we merge in Census tract median family income and demographic data for the 2011-2018 period from the American Community Survey. ${ }^{10}$

Imputation of Auto Term. Only 21 percent of the observations in our sample have term-tomaturity recorded. In most other cases (69 percent of the sample observations), we imputed the missing values using reported information on required monthly payment and the change in the

\footnotetext{
7 Term-to-maturity is reported for 9 percent of the loans in the sample.

${ }^{8}$ Exclusion of leases reduces the sample size by about 12 percent, to around 11.5 million accounts.

${ }^{9}$ Census tract code is intermittently reported in the FRBNY Equifax CCP; we used the most recently reported tract code.

10 We accessed the American Community Survey data via the Federal Financial Institutions Examination Council's Census File, https://www.ffiec.gov/censusapp.htm.
} 
principal balance across observation dates. A model-based imputation was applied to the remaining 10 percent of observations with missing term-to-maturity information, leaving only 0.6 percent of the sample without a recorded or imputed value for this variable. ${ }^{11}$ Details on the imputation procedure are provided in Appendix 1.

Next, we restrict the sample to loans with a reported or imputed term that exceeds 48 months. Excluding shorter-term loans simplifies the analysis by reducing the sample heterogeneity. Moreover, because our focus is on borrowers' decisions whether to opt for a long term loan, a term of 48 months or less would seem be well outside of their marginal decision space. When this restriction is imposed, the sample size declines to 8.9 million accounts.

Finally, nearly 2 percent of the sample is excluded from the analysis because of missing geographic or other information. ${ }^{12}$ The final sample contains around 8.2 million accounts belonging to about 5 million individual consumers. ${ }^{13}$ Although most of the analysis is conducted at the account level, we confirm the robustness of the analysis to applying sample weights so individual consumers are equally weighted regardless of the number of auto loans they have.

Limitations of the Data. Despite offering a diverse set of borrower and loan characteristics, the consumer credit record data from which our sample is derived lack some important, potential drivers of term choice or delinquency risk that are observable to the lender and borrower. These include the loan-to-value (LTV) ratio at origination, which is the value of the vehicle financed with the loan as opposed to using the borrower's own funds in the form of cash or trade. Other unobserved factors include vehicle characteristics (make, model, trim levels, and used versus new auto), the number and type of other relationships the borrower may have with the lender, and the borrower's employment status and or income (self-reported or verified).

Another data limitation, particularly affecting the analysis of term selection, is the inability to observe key factors such as household wealth and family size that may jointly influence the choice of

\footnotetext{
${ }^{11}$ The use of the model-based imputation for 10 percent of the observations introduces a small amount of endogeneity into the relationship of the loan term to the likelihood of default because of the inclusion of Equifax Risk Score as a predictor in the imputation model. Our empirical findings on likelihood-of-default are robust to excluding this portion of the sample.

12 Most of these are dropped due to missing Census tract. A few are missing the Risk Score or age of the oldest credit account.

13 The majority (57 percent) of these consumers have only one auto loan originated over the sample period; 24 percent have two loans; and 2.7 percent have five or more loans.
} 
both the amount borrowed (and, in turn, the required monthly payment) and the term-to-maturity. Many borrowers may take out longer maturity loans so they can buy more expensive cars with larger loans and still afford the monthly payment. That is, they would be deciding on the loan amount, monthly payment, and term simultaneously.

Simultaneity of the loan amount and term rules out direct inclusion of the loan (or payment) amount as an explanatory variable in the term choice equation. Because of this data limitation, we rely on measures of an individual's past borrowing as proxies for the current amount borrowed. Specifically, we include an indicator of whether the new loan simply replaces a prior loan versus adding to any existing auto loans, total balance of prior auto loans, and the original amount of the largest prior auto loan. ${ }^{14}$

Table 1 reports the correlation in our sample among these variables and the amount of the newly originated loan. Replacing an existing loan exhibits a moderate, positive correlation with the size of the new loan (about 20 percent). As expected, the total balance of prior loans and the original amount of the largest prior loan are strongly positively correlated with the amount of the new loan (about 60 and 40 percent, respectively).

FR Y-14Q Sample. In addition to the main sample, we use segment-level data collected by the Federal Reserve Board from banking organizations, subject to regulatory requirements of the DoddFrank Act, known as the FR Y-14Q reports. ${ }^{15}$ We rely on these data to conduct a separate, supplementary analysis of trends in the credit quality of auto loans.

The FR Y-14Q reports collect data on bank holding company risk exposures for various asset classes, including auto loan portfolios, on a quarterly basis.

For the domestic auto loan and lease asset class, the FR Y-14Q report delineates three product type segments: six segments for loan age, four segments for LTV at origination, and five for borrower

\footnotetext{
${ }^{14}$ For this purpose, a prior auto loan is any active auto loan in the individual's credit report as of six months preceding the origination data of the new loan. The new loan replaces a prior loan if the total number of active auto loans is unchanged relative to six months before. The total balance of prior auto loans is the total balance on these loans as of six months before (zero if there is no prior loan) the origination of the current loan. The original amount of the largest prior auto loan is the maximum original loan amount among all prior loans (zero if there is no prior loan). Nearly half of the sample (47.4 percent of observations) has a prior loan indicated.

15 The data are used by the Federal Reserve to support the annual Dodd-Frank stress tests and other supervisory activities.
} 
credit score at origination ("industry standard credit score or equivalent"). In addition, the reports further subdivide these into six geographic segments; and five delinquency status segments, although we do not make use of the latter disaggregation. For our analysis, we use information on total loan count by segment; the data also provide total outstanding balances and some segment-level summary variables.

\section{Trends in Auto Borrowing and Default}

Auto lending has grown rapidly since 2012, as seen in Figure 1. At the end of 2018, outstanding auto loan and lease balances stood at $\$ 1.3$ trillion, the second largest category of consumer debt exclusive of closed-end mortgages, which is not far behind the $\$ 1.5$ trillion of student debt, and exceeding the $\$ 0.9$ trillion of credit card debt. This growth has been accompanied by various trends in borrower characteristics, as summarized in Tables 1, 2, and 3.

Panel A of Table 2 shows the proportion of auto loans originated each year to individuals who have a mortgage loan outstanding during the 2011-2018 period. Those with mortgages are homeowners, while many of those without mortgages are renters. Renters typically are less creditworthy because they tend to be younger and have smaller incomes and savings. The table indicates an upward trend in the proportion of auto loans originated to individuals without mortgages.

Panel B of Table 2 provides the sample mean values of selected borrower and loan characteristics by year-of-origination during the 2011-2018 period, distinguishing between borrowers with and without a mortgage. Consistent with our observation that renters are typically less creditworthy, we see that borrowers without a mortgage are younger, have lower average Risk Scores, have higher credit card utilization rates, and reside in neighborhoods with lower median family incomes.

Among borrowers with a mortgage, average Risk Score increases through the entire period, consistent with improving credit quality. Among borrowers without a mortgage, average Risk Scores decrease until 2016, indicating declining credit quality.

For both cohorts (those with and without a mortgage), we observe a clear trend of rising loan amounts, measured by mean originated amount or proxied by the conditional mean value of prior auto loan balances (conditional on having one or more auto loans outstanding as of six months prior). In both cohorts, the distribution of the borrower population is shifting toward Census tracts with 
lower median family incomes, and auto-loan payment amounts are increasing relative to tract median family income. Although these trends are indicative of increasing default risk, county unemployment rates and (over the latter part of the period) credit card utilization rates are declining, tending to mitigate default risk.

Figure 2 shows the distribution of loans originated each year during the 2011-2018 period, across three term-to-maturity ranges: loans with terms of less than five years (but greater than 48 months); more than five and up to six years; and long (more than six years) terms, again distinguishing between borrowers with and without a mortgage. The term-to-maturity of newly originated auto loans steadily lengthened over this period. In the 2011-2018 period, in each cohort, the share of long-term loans about doubled, from about 15 percent to about 30 percent, while the share in the five year or less range declined about 50 percent.

Figure 3 shows the distribution of loans originated each year during the 2011-2018 period across the three term-to-maturity categories by four Risk Score ranges: less than or equal to 620 , greater than 620 and less than or equal to 660, greater than 660 and less than or equal to 720, and greater than 720 . We observe that the share of long-term loans rose steadily within each range, with larger proportional increases within higher Risk Score ranges, over this period. For 2011, we observe that the share of long-term loans is inversely related to Risk Scores across the four ranges, declining from 24 percent in the lowest Risk Score range to just 9 percent in the highest. As of 2018, about onethird of originations in the lower three Risk Score range, and about one-fourth in the highest Risk Score range, have terms longer than 72 months.

Figure 4 shows the distribution of loans originated each year during the 2011-2018 period across the four lender-type categories defined in the FRBNY Equifax CCP data, separately for borrowers with and without a mortgage. We observe that auto-finance companies consistently originate about half of the loans issued to borrowers without a mortgage. The share of auto loans originated by credit unions increased steadily over this period, particularly within the cohort with a mortgage. The "other" lender type category has only a small share of originations, just 3 percent on average across the years. ${ }^{16}$

\footnotetext{
16 The other category incorporates loans from auto or truck dealers (other than bank or finance company
} loans originated through dealers), from personal loan companies, or other miscellaneous sources. 
Default Rate Trends. Figure 5 shows the percentage of loans originated in 2011 through 2016 that default within the first 24 months after origination, by origination year, for the sample overall and separately for borrowers with and without mortgages. Default is defined as becoming 90 or more days past due.

For the cohort of borrowers without a mortgage, the default rate gradually increases from 4.9 percent to 5.9 percent between 2011 and 2014, jumps to 7.1 percent in 2015, and marginally increases to 7.3 percent in 2016. For the cohort with a mortgage, the default rate declines slightly from 1.3 percent to 1.1 percent between 2011 and 2014, and then increases marginally to 1.3 percent in 2015 and 1.4 percent in 2015.

Trends Observed in the FR Y-14Q Data. As we have noted, the FRBNY Equifax CCP data lack information on some important loan characteristics that may influence the choice of loan term or indicate credit quality. In particular, we do not observe in these data whether borrowers are financing new or used automobiles, and we do not observe the initial LTV. Using FR Y-14Q data, we can calculate the distribution of new auto loans for each annual origination cohort in the 2011-2018 period across new versus used car and initial LTV segments, as well as across borrower credit score ranges. An important caveat is that the observed distributions are those of the large banking organizations that submit FR Y-14Q data and are not necessarily representative of the broader auto lending market.

As with the credit reporting data, we exclude the lease product segment from the FR Y-14Q data; that is, we restrict attention to the two product segments, loans for new and used autos, respectively. We also limit attention to the single-age segment of less than one year since origination, which approximates newly originated loans.

The calculated distributions for the FR Y-14Q sample are shown in Figure 6, Panels A through C. Only modest or marginal shifts in the sample composition over time are observed.

Panel A of Figure 6 shows the distribution of newly originated loans across the ranges of borrower credit score, by year-of-origination. We observe a modest increase between 2011 and 2014 in the share of loans in the lower credit score ranges (credit scores below 660), and a partial reversal of this shift after 2016 (a small decline in the share originated to borrowers with credit scores below 620). 
Panel B of Figure 6 provides the distribution of newly originated loans across the ranges of origination LTV and borrower credit score, by year of origination. Between 2011 and 2015 (mostly prior to 2015), within each credit score range, the distribution shifted marginally toward higher LTV ratios. After 2015, the distribution shifted slightly back toward lower LTV ratios.

Panel C of Figure 6 shows the distribution of newly originated loans across the ranges of borrower credit score and new versus used car segment, by year-of-origination. The share of loans for financing used car purchases shows little variation across credit score ranges or over time, ranging between 50 percent and 55 percent. In each credit score range, the share of loans financing used car purchases declined by 1 or 2 percentage points between 2011 and 2016 .

\section{Model for Choice of a Long Loan Term}

We estimate a standard logit model to predict the likelihood of a consumer choosing a loan term with a maturity of more than 72 months (which, given our prior sample restriction, is conditional on the choice of a term greater than 48 months). We focus on this binary choice because we are interested in the factors associated with the expanded offering and takeup of long-term loans since 2011 . The model takes the form:

$$
\operatorname{Pr}\left(L_{i}=1\right)=\frac{1}{1+e^{-\left(\alpha+X_{i} \beta+Y_{i} \gamma\right)}}
$$

where $L_{i}$ takes value of 1 if the loan term exceeds six years and 0 otherwise; $X_{i}$ is a vector of loan and borrower characteristics and Census tract and county-level variables; $Y_{i}$ is a vector of dummy variables identifying year-of-origination ("origination vintage"); and $\alpha$ is an intercept parameter and $\beta$ and $\gamma$ are coefficient vectors to be estimated. Separate equations are estimated for individuals with and without a mortgage.

If loan $i$ is originated in year $y$, then the vintage dummy variable corresponding to year $y$ is set equal to 1 , and all other vintage dummy variables take the value of 0 . Vintage indicators are included for each year in the 2011-2017 period. The excluded year 2018 is the baseline year, such that the estimated vintage effect for year $y$ indicates the relative likelihood of a consumer choosing a long loan term in year $y$ in comparison to 2018 , all else equal.

In selecting variables to include in $X_{i}$, we combine economic reasoning with statistical evaluation. We start with a core set of variables that reasoning suggests might relate to borrower preference for a long-term loan. These include the borrower's Risk Score and credit card utilization 
rate, along with the median family income of the Census tract and the unemployment rate in the county where the borrower resides. We expect that borrowers with higher Risk Scores and lower card utilization rates, and those who reside in higher income or lower unemployment areas, will tend to have higher incomes or savings and, hence, less need for a longer term that reduces their monthly payment amount.

The core set also includes our proxies for loan size; all else equal, borrowers desiring larger loans are more likely to favor longer terms to make the monthly payment more affordable. In addition, we include a set of dummy variables as standard controls, indicating the borrower's age range, dummy variables indicating lender type, and dummy variables for ranges of percent minority population of the Census tract where the borrower resides.

Alternative constructions were considered for this core set of variables. For example, we chose to include indicator variables for three ranges of Risk Score after considering various alternative representations. ${ }^{17}$

We also tested the inclusion of a variety of additional factors drawn from the borrower's credit report, beyond the core set. The final model specification was based on considering the statistical and economic significance of each variable. We also considered whether the inclusion of a variable would materially improve the model's in-sample fit; that is, its ability to separate borrowers by the event outcome (choice of a long-term loan), without introducing excessive multicollinearity. ${ }^{18}$

Estimation Results. The final set of variables selected for the model is listed and defined in Table 3. Beyond the core set of variables and the origination vintage indicators, the model incorporates a few factors that intuitively seem related to borrower income or access to liquidity. These include indicators for having at least one credit card, having a student loan, and whether a borrower with a mortgage also has a home equity line of credit (HELOC). In addition, the model includes an indicator of whether, for those with student loans, the remaining principal balance

\footnotetext{
${ }^{17} \mathrm{We}$ also tested the interaction of the Risk Score range indicators with lender type but found no important impact on model results. In addition, we tested the interaction of total prior auto loan balance with the indicator for the new loan as a replacement of a prior loan, but it was not statistically significant and did not affect other estimated coefficients.

18 We favored inclusion if it materially increased the model C-statistic and K-S statistic. Variance inflation factors were examined to assess multicollinearity.
} 
exceeds 75 percent of the original loan amounts. Aside from the HELOC indicator, the same variables are selected for each of the two cohorts (with and without mortgages).

Tables 4 and 5 present the estimation results for the cohorts with and without a mortgage, respectively. The C-statistic and KS-statistic for the combined models on the full sample (pooling borrower with and without a mortgage) are 0.68 and 0.27 , respectively, indicating reasonable discrimination between term choice outcomes. The ROC curve depicting discriminatory performance for the combined models is shown in Appendix 2.

Estimated relationships are similar across the two cohorts. Borrowers in the highest Risk Score range have the lowest likelihood of choosing a long loan term, and those with Risk Scores between 660 and 720 have a lower likelihood of choosing a long term than those with Risk Scores between 620 and 660. These relationships are consistent with the expectation that borrowers with higher Risk Scores are less liquidity constrained and, hence, have less need for a longer term that would reduce their monthly payment amount.

However, the relationship to Risk Score reverses at the lower end of the Risk Score range, as borrowers with Risk Scores below 620 have a relatively low likelihood of selecting a long term. A plausible interpretation is that lenders restrict access to long-term auto loans to the lowest credit quality borrowers because of the likely consequences for default risk from such layering of risk factors. This nonmonotonic relationship may be one reason why we observe little overall difference across the two cohorts regarding the propensity to select a long loan term, despite the differences in average Risk Score. ${ }^{19}$

Borrowers with a higher credit card utilization, those who reside in neighborhoods with a lower median income or in counties with a higher unemployment rate, and those who have a large proportion of their original student loans not yet paid off are more likely to opt for a long loan term. Again, these relationships are consistent with intuition since these factors are indicators of reduced debt payment capacity, which could motivate the choice of a long loan term. Also, as expected, larger amounts borrowed in the past, our proxy measures for the amount borrowed on the new loan, are associated with the selection of a long loan term.

${ }^{19} \mathrm{An}$ additional, possible explanation is that there may be a larger percentage of used car buyers in the cohort without a mortgage, offsetting the tendency of lower-income borrowers to favor longer terms. 
Borrowers with at least one credit card and those with a HELOC are less likely to opt for a long term. These characteristics indicate greater access to backup liquidity, which may position a borrower to better afford the higher monthly payment associated with a shorter loan term. ${ }^{20}$

Auto financing companies, which include financing arms of auto manufacturers (known as captives) as well as independent auto finance companies (these subcategories are not distinguishable in our data), are less likely to extend long term loans. This outcome may reflect the well-known propensities of noncaptive finance companies to serve a subprime clientele and of captives to offer low rates on traditional auto loans as incentives to car buyers.

Quantifying the Role of Origination Vintage Effects. For both cohorts, the estimated odds ratios associated with the year-of-origination (origination vintage) dummy variables $Y_{i}$ indicate a continual increase in the likelihood of choosing a long loan term over 2011 through 2018 . We further quantify the contribution of origination vintage effects by calculating the implied probability of choosing a long loan term for each observation based on the estimated equations and the implied probability minus the estimated vintage effect. Note that, since vintage indicators are included for each year except 2018 (which is the baseline), subtracting an estimated vintage effect is analogous to assuming that the loan was originated in 2018. We then calculate the mean of these probabilities by borrower cohort and year of origination.

The results from these calculations are shown in Figure 7; Panel A displays the cohort without a mortgage and Panel B displays the cohort with a mortgage. The results are similar across the two cohorts. Although the actual proportion of borrowers choosing a long term monotonically increases over the period, the implied proportion without vintage effects is essentially flat at about 30 percent. $^{21}$

Thus, the increasing share of long-term loans is largely attributed to nonspecific, year-oforigination effects, rather than to factors identifiable in our data. Although the identifiable factors in $X_{i}$ provide differentiation of the likelihood of choosing a long loan term across borrowers, this likelihood has been increasing over time for all borrowers. Factors not directly observed, such as

\footnotetext{
20 We also tested a specification with the HELOC indicator redefined as whether the borrower has a HELOC that is less than fully utilized (utilization rate of less than 75 percent). This redefinition does not materially alter the estimated relationships.

${ }^{21}$ For each origination vintage, the mean implied probability with the vintage effect included is virtually identical to the observed proportion of sample loans having a long term.
} 
shifts in the balance sheet and liquidity composition of the borrowing population, would have propelled this trend.

Estimation Results for the Sample Restricted to Banks Only. One factor not directly observed in our data is borrower preference for a new versus a used car. It is conceivable that borrowers increasingly favor new cars, which leads them to choose a larger loan and opt for a longer term.

Our previous examination of trends in the FR Y-14Q data do not support such an explanation, since the share of loans used to finance new cars has not varied much over time in these data. However, the FR Y-14Q data are collected from bank holding companies and may not reflect trends in the auto-loan market overall. The increasing share of long-term loans may reflect the increased share of loans financing new cars, specifically within the nonbank segment of the market.

In that case, however, we should not observe origination vintage effects, or we would expect those effects to be weaker, with the sample restricted to bank originated loans. Therefore, we can evaluate the plausibility of this explanation by reestimating the equation for the choice of a long loan term with the sample restricted to auto loans originated by banks.

Tables 6 and 7 present the estimation results for the cohort with and without a mortgage, respectively, with the estimation sample restricted to bank originated loans. For both cohorts, the estimated odds ratios associated with the year-of-origination (origination vintage) dummy variables

$Y_{i}$ indicate a continual increase in likelihood of choosing a long loan term over the 2011-2018 period. Moreover, these estimated effects are comparable in magnitude to the full sample estimates reported in Tables 4 and 5. Thus, we do not find support for the view that the increasing share of long-term loans is tied to an increased share of loans financing new cars.

\section{Default Model}

Next, we estimate a standard logit model to predict the likelihood of a borrower defaulting within two years after the loan is originated. We define a loan as in default if it is 90 days or more days past due or if the borrower is in bankruptcy, or the auto is in repossession. To observe a loan's performance over a full, two-year period, we restrict attention to loans originated in the 2011-2016 period. The model takes the form:

$$
\operatorname{Pr}\left(y_{i}=1\right)=\frac{1}{1+e^{-\left(\alpha+T_{i} \delta+X_{i} \beta+Y_{i} \gamma\right)}}
$$


where $y_{i}$ takes a value of 1 if the loan defaults within 24 months, and 0 otherwise; $T_{i}$ is a pair of dummy variables distinguishing the three term-to-maturity ranges defined previously (with long term as the omitted category); and $X_{i}$ a vector of loan and borrower characteristics and Census tract and county-level variables. Again, $Y_{i}$ represents the set origination vintage dummy variables, $\alpha$ is an intercept parameter, and $\delta, \beta$, and $\gamma$ coefficient vectors are to be estimated. Vintage indicators are included for each year except 2016 (which is the baseline year). We again estimate separate equations for individuals with and without a mortgage.

Again, we start with a core set of intuitively important explanatory variables for inclusion in $X_{i}$. We test alternative constructions for these variables, and then evaluate inclusion of a variety of additional factors drawn from the borrower's credit report, beyond the core set.

With two exceptions, we start with the same set of core variables used in the modeling choice of a long loan term, as reasoning suggests that these factors also should influence a borrower default risk. One exception is that in the context of modeling repayment performance, the original loan amount can be reasonably viewed as predetermined, and we therefore include it directly in the core set in place of the previously used proxy variables. The second exception is that we can also now view the monthly required payment on the auto loan as predetermined. Therefore, we include the ratio of monthly payment amount to median family income of the Census tract where the borrower resides.

Estimation Results. The final set of variables selected for the model is listed and defined in Table 8. Alongside the core set of variables, the term-to-maturity dummy variables, and the origination vintage indicators, the model incorporates a few additional factors that plausibly relate to a borrower's financial condition. ${ }^{22}$

The latter include indicators for having at least one credit card, having a student loan; and whether a borrower with a mortgage also has a HELOC. Also included are a pair of dummy variables distinguishing three ranges of monthly payment amounts for first-lien mortgages, a dummy variable distinguishing single borrowers (versus those who have a coborrower), and the indicator of whether the new loan replaces a previous auto loan or adds to the consumer's existing auto loans. Aside from

\footnotetext{
${ }^{22}$ We tested the interaction of the Risk Score range and term length indicators but found an insignificant impact on estimated relationships and no improvement in model fit, and therefore opt for the simpler, linear specification.
} 
the mortgage payment amount and HELOC indicators, the same variables are selected for each of the two cohorts (with and without mortgages).

Tables 9 and 10 present the estimation results for the cohorts with and without a mortgage, respectively. The C-statistic and KS-statistic for the combined models on the full sample (pooling borrower with and without a mortgage) are 0.85 and 0.58 , respectively, indicating a strong discrimination between default outcomes. The ROC curve depicting discriminatory performance for the combined models is shown in Appendix 2.

Estimated relationships are mostly similar across the two cohorts. The likelihood of default is inversely related to Risk Score and to the median income of the Census tract where the borrower resides. The likelihood of default is positively related to credit card utilization rate, the ratio of monthly auto-loan payment to Census tract median family income, and the county unemployment rate. Individuals with at least one bankcard, and those who have a coborrower, have a lower likelihood of default on their auto loan.

The relationship between the original loan amount and the likelihood of default differs between cohorts with and without a mortgage. For the cohort with a mortgage, the lowest balance range is associated with the highest risk of default. In contrast, for the cohort without a mortgage, those in the lowest balance range are less likely to default than those in the middle range. In both cohorts, however, the highest balance range is associated with the lowest likelihood of default. An intuitive interpretation of the latter relationship is that individuals purchasing relatively expensive cars tend to have higher incomes and be more financially stable.

Relationship to Term Length. The comparative likelihood of default across the three termlength categories also differs between borrowers with and without a mortgage. For the cohort with a mortgage, loans with a long term (more than six years) are the most likely to default. Thus, for this cohort, the preference for a long term and a higher likelihood of default is associated with a common unobserved factor, such as having less savings or liquidity, consistent with the tendency to associate with the same observed factors. For the cohort without a mortgage, however, the shortest-term category (five years or less) is associated with the highest likelihood of default.

The inconsistency across the two cohorts regarding the comparative default risk associated with a long loan term underscores the influence of unobserved factors on the propensity to default. For example, a plausible explanation for the elevated default likelihood of a five-year loan among 
borrowers without a mortgage is that a relatively high percentage of those loans may be for borrowers purchasing used cars, who tend to have a lower credit quality. However, whether a borrower is purchasing a new or used car is not indicated in our data.

For both cohorts, a long loan term is associated with a higher likelihood of default relative to a term more than five and up to six years in length. Thus, in comparison to the neighboring termlength segment, a long loan term aligns with a higher likelihood of default through a shared association with unobserved factors.

Although borrowers opting for long loan terms are more likely to default in three of the four term-length comparisons, the increasing share of borrowers selecting a long loan term between 2011 and 2016 did not materially contribute to the rise in default rates. This is evident from simple calculations based on the estimated odds ratios for the term-to-maturity dummy variables in the default equation. For instance, for the cohort with a mortgage, if in 2011, 24 percent of borrowers (instead of the actual 15 percent) had opted for a long loan term, as in 2016, the default rate for 2011 would have been 20 basis points higher. 23

Quantifying the Role of Origination Vintage Effects. For both cohorts, the estimated odds ratios associated with the set of origination vintage dummy variables $Y_{i}$ indicate a large increase in the likelihood of default for the 2015 and 2016 origination vintages, relative to earlier vintages. The vintage effects also indicate a decline in the likelihood of default between 2011 and 2014 for the cohort with a mortgage and an increase in the likelihood of default over that period for the cohort without a mortgage.

We further quantify the contribution of origination vintage effects by calculating for each observation the implied probability of default from the model with and without the estimated vintage effect. Note that, since vintage indicators are included for each year except 2016 (which is the baseline), subtracting an estimated vintage effect is analogous to assuming that the loan was

\footnotetext{
${ }^{23}$ For the cohort with a mortgage, borrowers with a loan term equal to or less than 72 months are 35 percent less likely to default and comprise 85 percent of 2011 originations. Given the overall default rate of 3.8 percent for this cohort, the implied underlying default rates are 5.4 percent for borrowers with a long loan term and 3.5 percent for the remaining group. Applying weights of 24 percent and 76 percent, respectively, to these default rates (to match the 2016 term-to-maturity distribution) implies an overall default rate of 4.0 percent.
} 
originated in 2016. We then calculate the mean of these estimated probabilities by borrower cohort and year of origination.

The results from these calculations are shown in Figure 8: in Panel A for the cohort without a mortgage and Panel B for the cohort with a mortgage. The results are similar across the two cohorts. Although the actual default rate in both cohorts jumps after 2014, the implied default rate without vintage effects is essentially unchanged between 2014 and 2016 for borrowers without a mortgage and mildly declines over this period for borrowers with a mortgage. 24

Thus, the jump in the default rate after 2014 is largely attributed to nonspecific, year-oforigination effects, rather than to factors identifiable in our data. Although the identifiable factors in $X_{i}$ provide differentiation of the likelihood of default across borrowers, this likelihood increased sharply after 2014 for all borrowers. Factors not directly observed, such as changes in the balance sheet and liquidity characteristics of the borrowing population, could have propelled this trend.

Estimation Results for the Sample Restricted to Banks Only. Two important risk factors are not directly observed in our data: the LTV at origination and whether the loan was for the purchase of a new versus a used car. Higher LTV loans and loans financing used cars generally are associated with a greater risk of default, so it is possible that the observed origination vintage effects for 2015 and 2016 reflect an increased share of high LTV loans or of loans financing used cars.

Our previous examination of trends in the FR Y-14Q data do not support such an explanation, since neither origination LTVs nor the share of loans used to finance new cars has varied much over time in these data. However, as previously noted, the FR Y-14Q data are collected from bank holding companies and may not reflect trends in the auto- loan market overall. The jump in the default rates after 2014 may reflect an increased share of high LTV loans or loans financing used cars, specifically within the nonbank segment of the market.

In that case, however, we should not observe these origination vintage effects, or we would expect those effects to be weaker, with the sample restricted to bank originated loans. Therefore, we can evaluate the plausibility of this explanation by reestimating the default equation with the sample restricted to auto loans originated by banks.

\footnotetext{
${ }^{24}$ For each origination vintage, the mean implied probability of default with the vintage effect included in the calculation is virtually identical to the observed mean default rate in the sample.
} 
Tables 11 and 12 present the estimation results for the cohort with and without a mortgage, respectively, with the estimation sample restricted to bank-originated loans. For both cohorts, the estimated odds ratios associated with the year-of-origination (origination vintage) dummy variables $Y_{i}$ again indicate elevated default rates for 2015 and 2016. Moreover, these estimated effects are comparable in magnitude to the full sample estimates reported in Tables 9 and 10. Thus, we do not find support for the view that the jump in default rates after 2014 is tied to an increased share of high LTV loans or loans financing used cars.

Alternative Specification Using Interest Rate. We also considered an alternative version of the model incorporating the loan's interest rate spread over the contemporaneous five-year Treasury bill rate; that is, the difference between the note rate and the Treasury rate. This measures default risk, which typically is priced into the interest rate on the loan. This is not our preferred specification because the interest rate on the loan is an imputed variable - a byproduct of the imputation procedure for loan term - and because of the loss of observations (we are unable to impute the interest rate for nearly 10 percent of the sample).

Estimation results for this version of the model are provided in Appendix 3 (Tables 13 and 14). As expected, the estimated coefficient on the interest rate spread is positive and statistically significant, but other estimation results are unaffected by inclusion of the additional measure.

\section{Concluding Summary}

This paper quantifies the relationships of long-term auto borrowing and auto-loan default to observable borrower characteristics and economic variables. In addition, we quantify the residual components of the trends in long-term borrowing and delinquency, which are not attributable to identifiable factors. The paper thus offers a best effort assessment of the degree to which the recent trends of rising long-term share and rising default rates may reflect factors not captured by traditional credit risk measures.

We find that factors observed to be associated with the choice of a long loan term also usually indicate increased risk of default. Both outcomes, for instance, are associated with a higher credit card utilization rate, a lower per capita income, and a higher local area unemployment rate.

The set of models we have estimated provide two important observations regarding longterm borrowing in relation to unobserved factors. First, rising long-term share reflects factors we do not observe, as captured by origination vintage effects. Second, borrowers choosing a long loan term 
have a relatively high likelihood of default in three of the four comparisons conducted, also because of factors we do not directly observe.

Likewise, we find that the rising frequency of auto-loan default is chiefly attributed to nonspecific, year-of-origination (fixed) effects, rather than factors observable from our data or observable to lenders. Although borrowers opting for long loan terms are more likely to default in most comparisons, we find that the increasing share of borrowers selecting a long loan term did not materially contribute to the rise in default rates. A key takeaway is that the traditional risk indicators that lenders rely on to originate auto loans would have failed to anticipate the deterioration in repayment performance. Factors not directly observable to auto lenders, such as shifts in the balance sheet and liquidity composition of the borrowing population, propelled both the rising share of longterm loans and rising auto-loan delinquency rates. 


\section{References}

Adams, William, Liran Einav, and Jonathan Levin (2009). "Liquidity Constraints and Imperfect Information in Subprime Lending," American Economic Review 99(1), pp. 49-84.

Agarwal, Sumit, Brent W. Ambrose, and Souphala Chomsisengphet (2008). "Determinants of Automobile Loan Default and Prepayment," Federal Reserve Bank of Chicago Economic Perspectives 32 (Third Quarter), pp. 17-28.

Argyle, Bronson, Taylor D. Nadauld, and Christopher Palmer (2019). "Monthly Payment Targeting and the Demand for Maturity," National Bureau of Economic Research Working Paper 25668, https://www.nber.org/papers/w25668.

Auto Trends Magazine (2016). "TransUnion: Longer Term Auto Loans Increase the Odds of Default," http://autotrends.org/2016/07/15/transunion-longer-term-auto-loans-increase-odds-ofdefault.

Guo, Zhengfeng, Yan Zhang. and Xinlei Zhao (2018). “Risks of Long-Term Auto Loans,” https://papers.ssrn.com/sol3/papers.cfm?abstract id=3290841.

Heitfield, Erik, and Tarun Sabarwal (2004). "What Drives Default and Prepayment of Subprime Auto Loans," Journal of Real Estate Finance and Economics 29(4), pp. 457-477.

Hertzberg, Andrew, Andres Liberman, and Daniel Paravisini (2018). "Screening on Loan Terms: Evidence from Maturity Choice in Consumer Credit,” Review of Financial Studies 31, pp. 35323567.

Lee, Donghoon, and Wilbert van der Klaauw (2010). "An Introduction to the FRBNY Consumer Credit Panel,” Federal Reserve Bank of New York Staff Report 479.

Melzer, Brian, and Aaron Schroeder (2017). "Loan Contracting in the Presence of Usury Limits: Evidence from Auto Lending," Consumer Financial Protection Bureau Office of Research Working Paper 2017-02, https://papers.ssrn.com/sol3/papers.cfm?abstract id=2919070.

Verma, Nidhi (2017). “Do Long-Term Auto Loans Cause Undue Risk?” RMA Journal 99(5), pp. 34-37.

Wardrip, Keith, and Robert M. Hunt (2013). "Residential Migration, Entry, and Exit as Seen Through the Lens of Credit Bureau Data," Federal Reserve Bank of Philadelphia Consumer Finance Institute Discussion Paper 13-4, https://papers.ssrn.com/sol3/papers.cfm?abstract id=2365794. 
Figure 1: Composition of Household Debt (Excluding Mortgage)

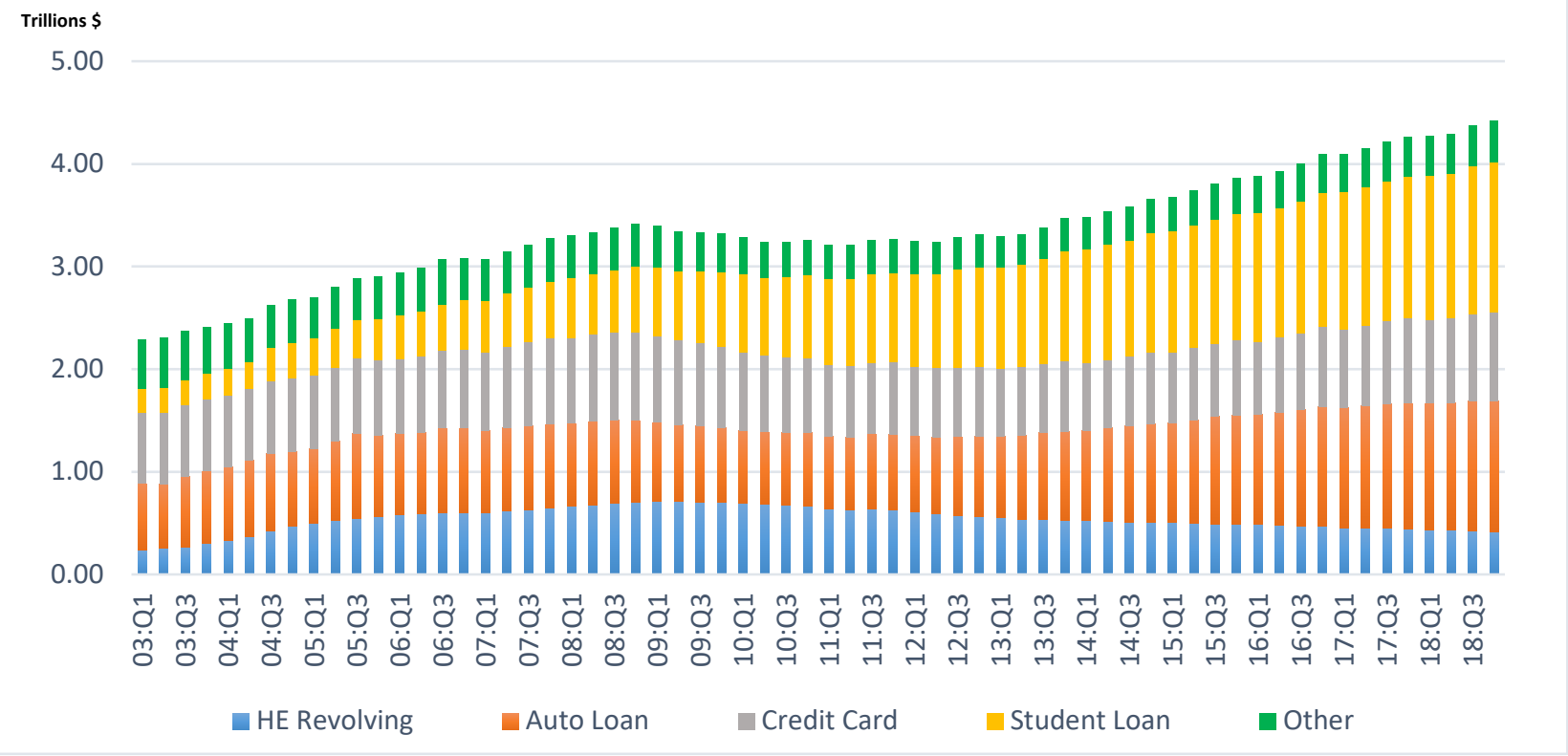

Source: FRBNY's Quarterly Report on Household Debt and Credit, excluding first-lien mortgage portfolio. 
Figure 2: Term-to-Maturity Distribution by Origination Year

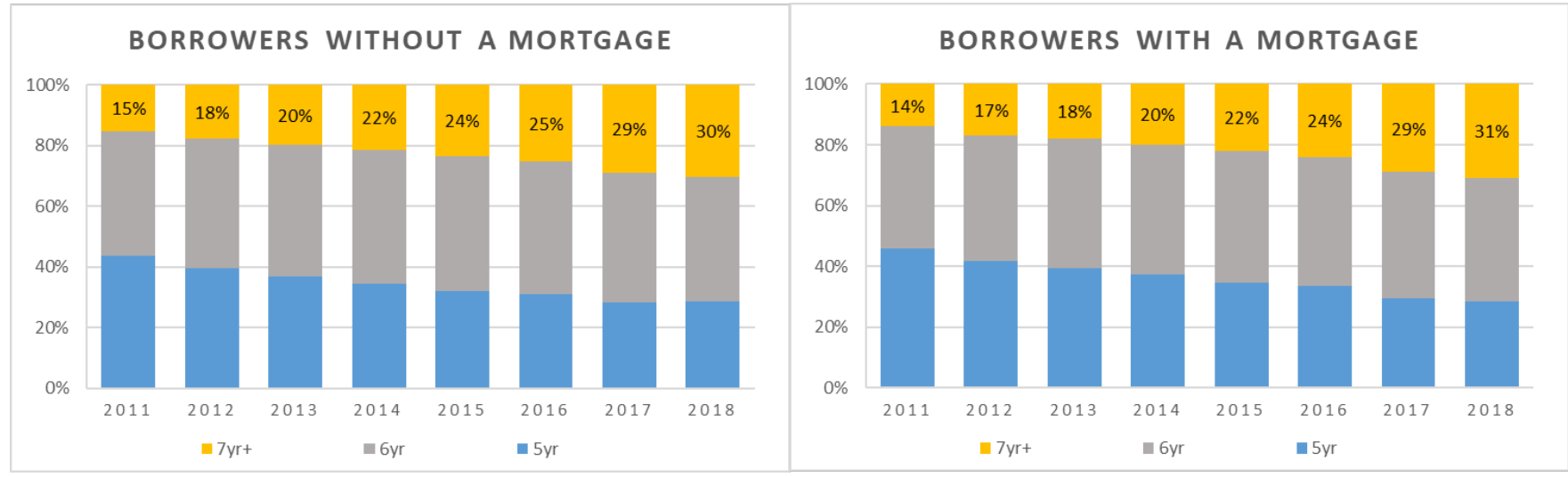

Source: FRBNY Equifax CCP. Sample restricted to loans with term-to-maturity > 48 months.

Figure 3: Term-to-Maturity Distribution by Origination Year and Risk Score Range

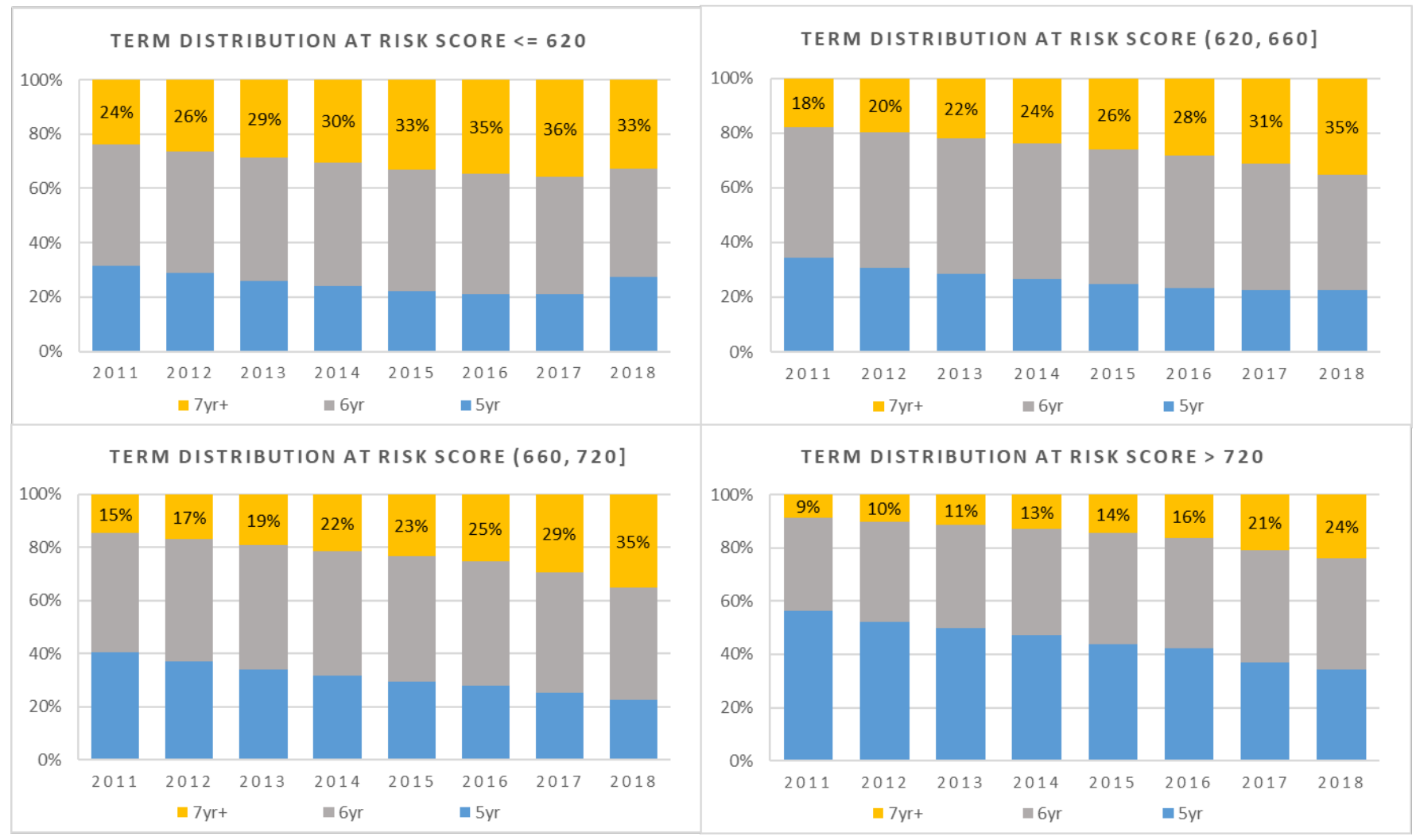

Source: FRBNY Equifax CCP. Sample restricted to loans with term-to-maturity $>48$ months. 


\section{Figure 4: Lender Type Distribution by Origination Year}

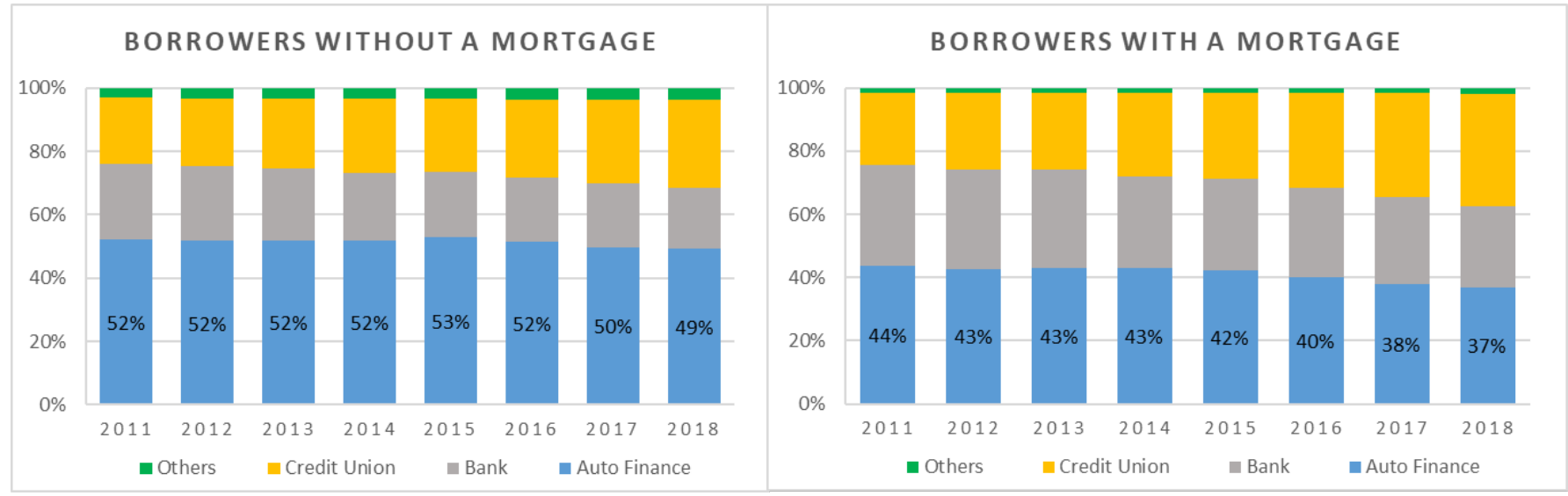

Source: FRBNY Equifax CCP. Sample restricted to loans with term-to-maturity $>48$ months.

Figure 5: Auto-Loan Default Rate by Origination Year and Borrower Mortgage Status

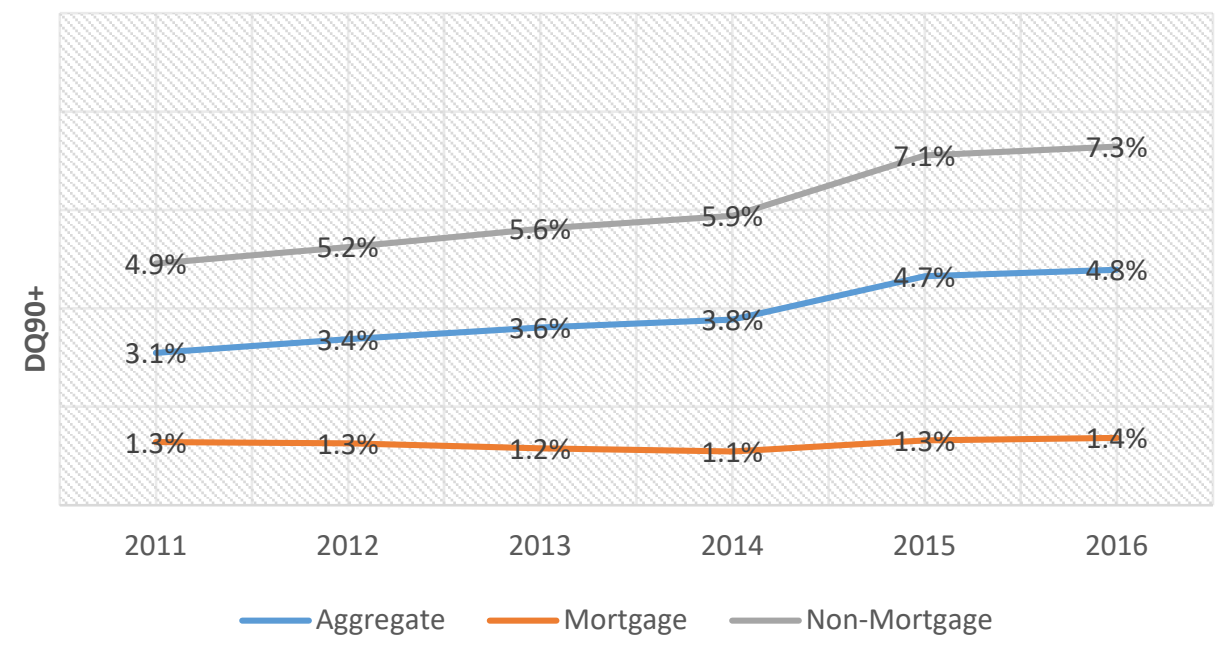

Source: FRBNY Equifax CCP. Sample restricted to loans with term-to-maturity $>48$ months; default defined as transition to 90 or more days past due within 24 months after origination. 
Figure 6: Risk Composition of the FR Y-14Q Sample by Origination Year

Panel A: Credit Score Distribution by Origination Year

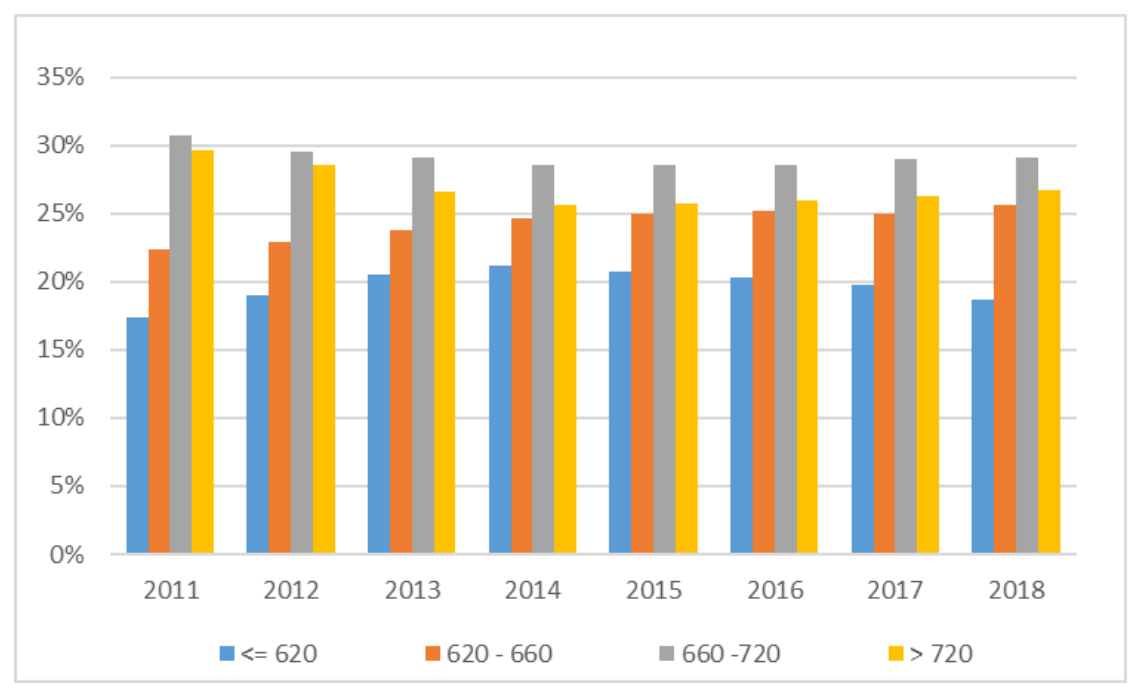

Source: FR Y-14Q

Panel B: Distribution of Initial Loan-to-Value Ratios by Risk Score Range and Origination Year

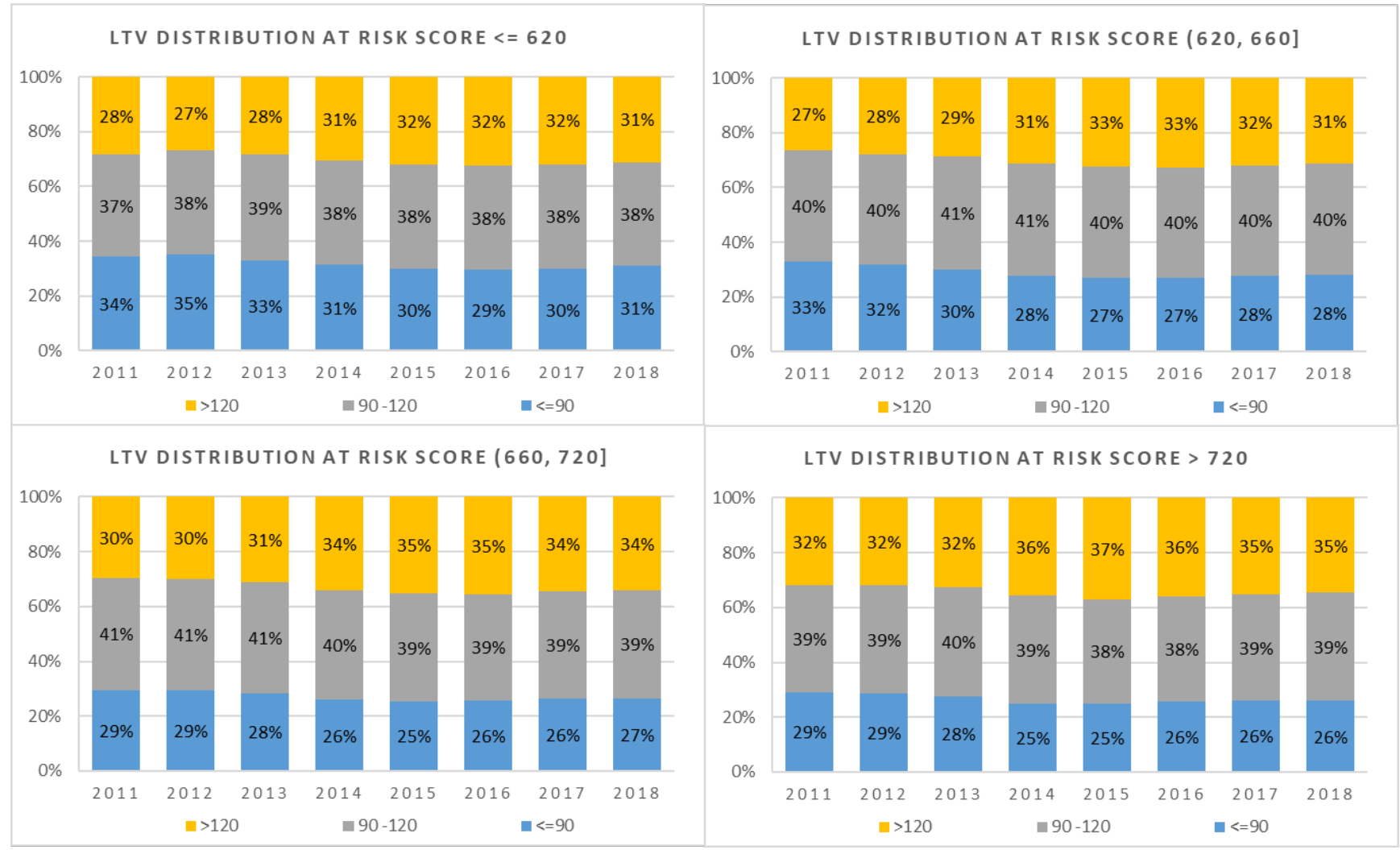

Source: FR Y-14Q 
Panel C: Used Car Share of Auto Loans by Origination Year

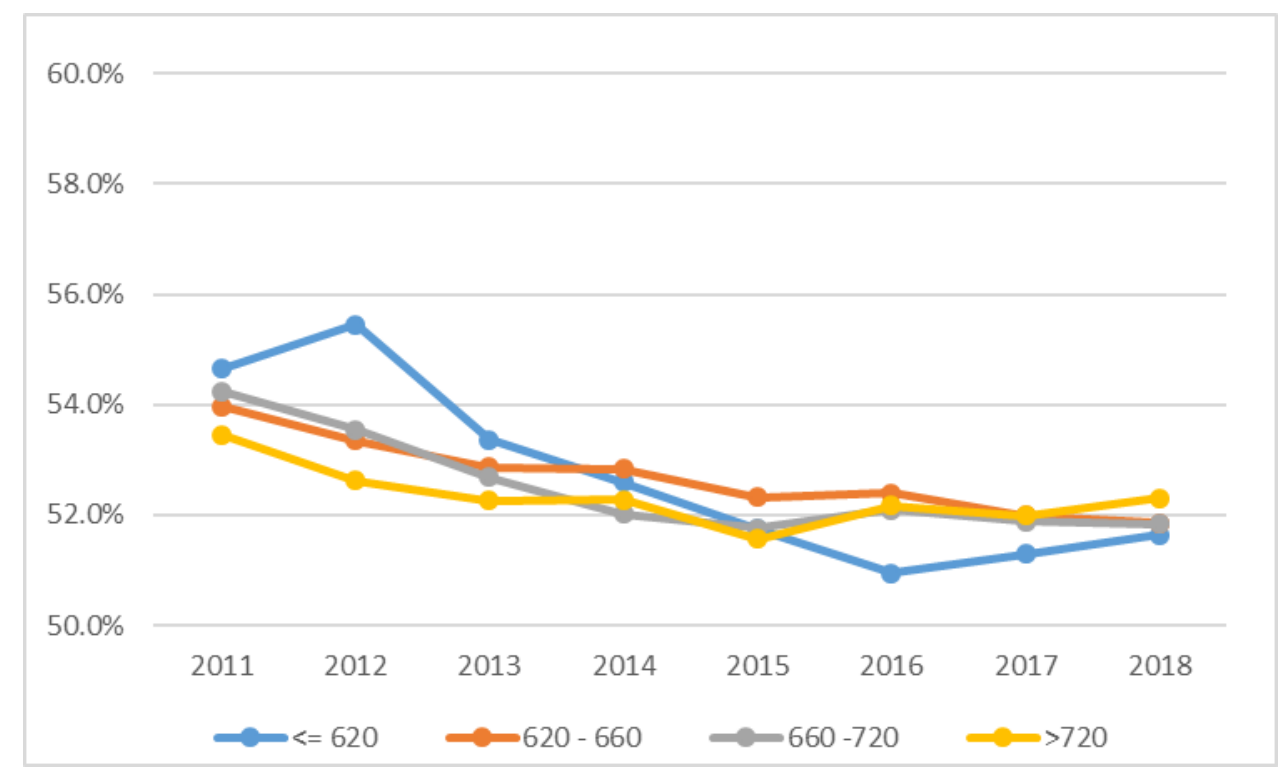

Source: FR Y-14Q

Figure 7: Origination Vintage Effects in the Term Choice Model

Panel A: Cohort Without a Mortgage

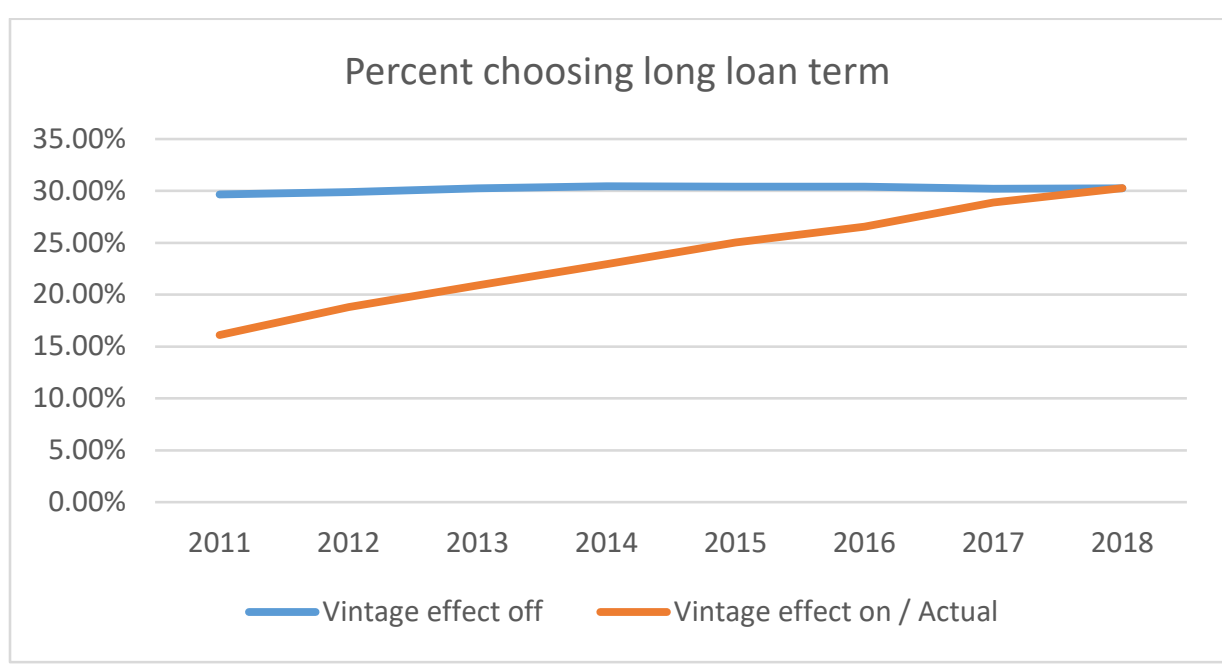

Source: FRBNY Equifax CCP. Sample restricted to loans with term-to-maturity $>48$ months. 
Panel B: Cohort with a Mortgage

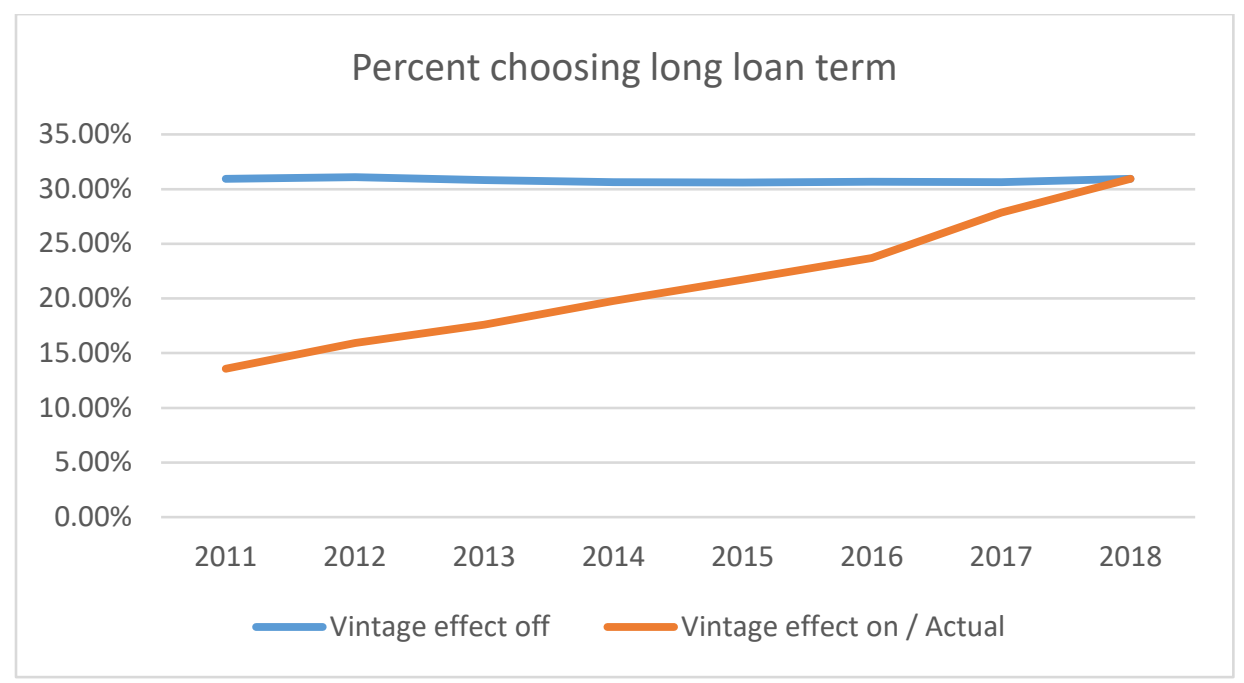

Source: FRBNY Equifax CCP. Sample restricted to loans with term-to-maturity $>48$ months.

\section{Figure 8: Origination Vintage Effects in the Default Model}

\section{Panel A: Cohort Without a Mortgage}

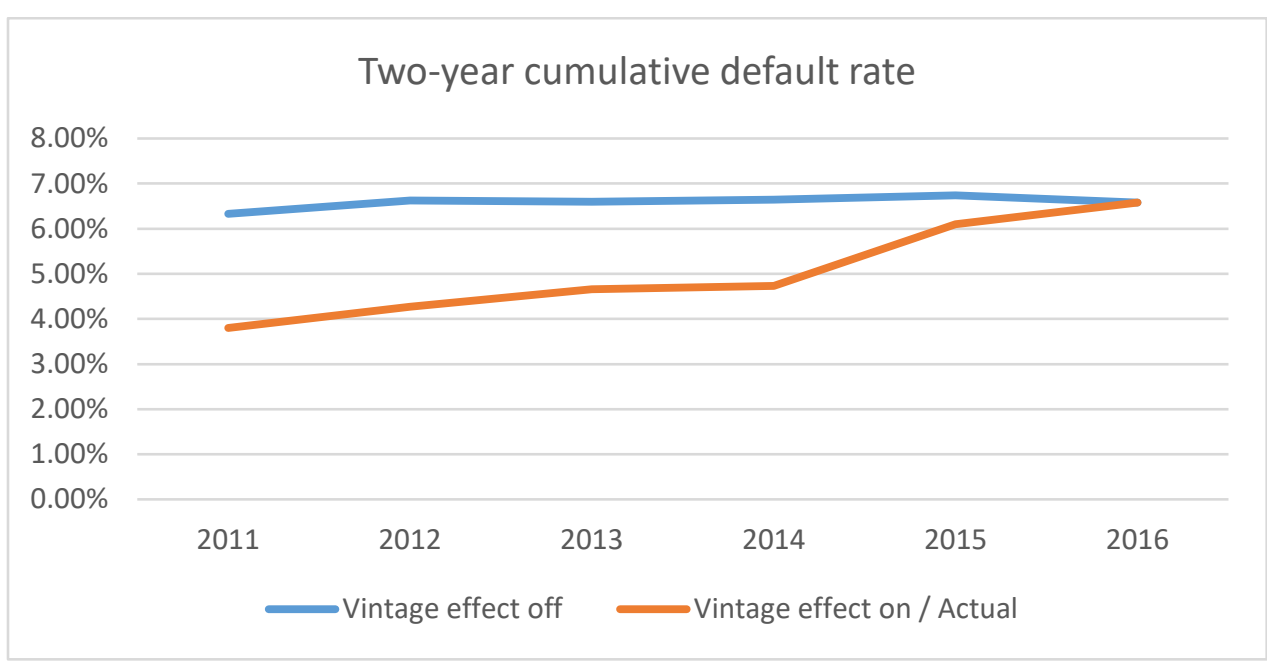

Source: FRBNY Equifax CCP. Sample restricted to loans with term-to-maturity $>48$ Months. 
Panel B: Cohort with a Mortgage

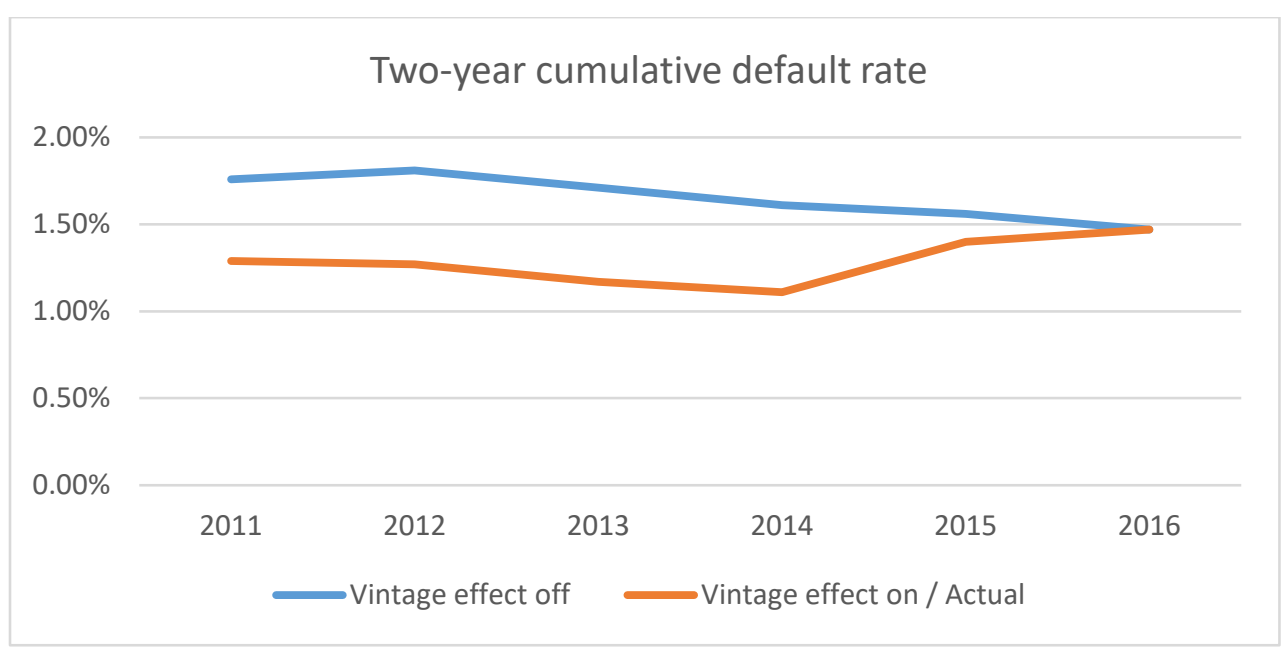

Source: FRBNY Equifax CCP. Sample restricted to loans with term-to-maturity $>48$ months. 
Table 1: Correlations Among Loan Amount and Measures of Past Borrowing

\begin{tabular}{|l|c|c|c|c|}
\hline & $\begin{array}{c}\text { New Loan } \\
\text { Amount }\end{array}$ & $\begin{array}{c}\text { New Loan } \\
\text { Replaces Existing } \\
\text { Loans }\end{array}$ & $\begin{array}{c}\text { Total Balance of } \\
\text { Prior Loans }\end{array}$ & $\begin{array}{c}\text { Original Amount of } \\
\text { Largest Prior Loan }\end{array}$ \\
\hline New loan amount & 1 & 0.188 & 0.575 & 0.406 \\
\hline $\begin{array}{l}\text { New loan replaces } \\
\text { existing loans }\end{array}$ & 0.188 & 1 & 0.069 & -0.005 \\
\hline $\begin{array}{l}\text { Total balance of } \\
\text { prior loans }\end{array}$ & 0.575 & 0.069 & 1 & 0.522 \\
\hline $\begin{array}{l}\text { Original amount of } \\
\text { largest prior loan }\end{array}$ & 0.406 & -0.005 & 0.522 & 1 \\
\hline
\end{tabular}

Source: FRBNY Equifax CCP, Haver Analytics, and FFIEC Census file. Sample restricted to loans with term-tomaturity $>48$ months. 
Table 2: Borrower and Loan Characteristics by Year of Origination

Panel A: Share of Auto Loan Originations by Mortgage Status of the Borrower

\begin{tabular}{|l|c|c|c|c|c|c|c|c|}
\hline & $\mathbf{2 0 1 1}$ & $\mathbf{2 0 1 2}$ & $\mathbf{2 0 1 3}$ & $\mathbf{2 0 1 4}$ & $\mathbf{2 0 1 5}$ & $\mathbf{2 0 1 6}$ & $\mathbf{2 0 1 7}$ & $\mathbf{2 0 1 8}$ \\
\hline $\begin{array}{l}\text { \% with } \\
\text { mortgage }\end{array}$ & $50.0 \%$ & $47.0 \%$ & $45.0 \%$ & $44.0 \%$ & $42.4 \%$ & $42.3 \%$ & $42.8 \%$ & $42.5 \%$ \\
\hline
\end{tabular}

Panel B: Selected Borrower and Loan Characteristics by Mortgage Status of the Borrower

\begin{tabular}{|c|c|c|c|c|c|c|c|c|}
\hline \multicolumn{9}{|c|}{ Non-Mortgage } \\
\hline Year & Risk Score & Age & Card Utilization & Loan Amount & $\begin{array}{c}\text { Prior Auto } \\
\text { Balance }\end{array}$ & Auto PTI & MFI & $\begin{array}{c}\text { Unemployment } \\
\text { Rate }\end{array}$ \\
\hline 2011 & 659 & 44 & 63.70 & 21212 & 22309 & 8.18 & 66658 & 9.30 \\
\hline 2012 & 654 & 44 & 64.39 & 21678 & 23018 & 8.29 & 66284 & 8.61 \\
\hline 2013 & 653 & 44 & 64.83 & 22068 & 23614 & 8.43 & 65744 & 7.95 \\
\hline 2014 & 651 & 44 & 64.80 & 22457 & 24039 & 8.59 & 64877 & 6.93 \\
\hline 2015 & 649 & 43 & 64.16 & 22957 & 24720 & 8.83 & 64160 & 5.92 \\
\hline 2016 & 650 & 43 & 62.78 & 23237 & 25310 & 8.90 & 63805 & 5.23 \\
\hline 2017 & 656 & 43 & 60.95 & 23561 & 25750 & 9.02 & 63978 & 4.91 \\
\hline 2018 & 659 & 42 & 59.93 & 23984 & 26751 & 9.36 & 63673 & 4.31 \\
\hline \multicolumn{9}{|c|}{ Mortgage } \\
\hline Year & Risk Score & Age & Card Utilization & Loan Amount & $\begin{array}{c}\text { Prior Auto } \\
\text { Balance }\end{array}$ & Auto PTI & MFI & $\begin{array}{c}\text { Unemployment } \\
\text { Rate }\end{array}$ \\
\hline 2011 & 723 & 50 & 46.17 & 24286 & 27004 & 7.63 & 74644 & 9.11 \\
\hline 2012 & 722 & 51 & 46.59 & 24917 & 27607 & 7.71 & 74195 & 8.39 \\
\hline 2013 & 724 & 51 & 45.69 & 25448 & 28193 & 7.73 & 74284 & 7.75 \\
\hline 2014 & 726 & 51 & 44.94 & 26101 & 28901 & 7.85 & 73907 & 6.73 \\
\hline 2015 & 727 & 51 & 44.41 & 27029 & 29968 & 8.06 & 73423 & 5.72 \\
\hline 2016 & 729 & 51 & 43.14 & 27685 & 30772 & 8.17 & 73350 & 5.06 \\
\hline 2017 & 734 & 50 & 41.75 & 28098 & 31429 & 8.28 & 73638 & 4.75 \\
\hline 2018 & 737 & 49 & 41.22 & 28444 & 32770 & 8.57 & 73247 & 4.18 \\
\hline
\end{tabular}

Source: FRBNY Equifax CCP, Haver Analytics, and FFIEC Census file. Sample restricted to loans with term-tomaturity > 48 months. 
Table 3: Variable Definitions and Sample Mean Values for the Long-Term Choice Model

\begin{tabular}{|c|c|c|c|c|c|c|c|c|c|}
\hline Variable & Label & 2011 & 2012 & 2013 & 2014 & 2015 & 2016 & 2017 & 2018 \\
\hline Equifax Risk Score & Equifax risk score & 693 & 688 & 686 & 685 & 682 & 684 & 689 & 693 \\
\hline Borrower Age & Borrower age & 47 & 47 & 48 & 47 & 47 & 46 & 46 & 45 \\
\hline MFI & Median family income at tract level & 70819 & 70129 & 69775 & 69182 & 68297 & 67958 & 71129 & 70878 \\
\hline Prior Auto Balance & Total balance of prior auto loans & 24844 & 25352 & 25824 & 26299 & 27051 & 27709 & 28273 & 29413 \\
\hline Auto High Credit & Total high credit amount of prior auto loan & 21364 & 21373 & 21504 & 21726 & 22048 & 22507 & 23178 & 23613 \\
\hline Percent Minority (Tract) & Percentage Minority at tract level & 30.49 & 31.43 & 32.17 & 32.79 & 33.63 & 34.00 & 34.97 & 34.65 \\
\hline Student Loan Balance to Line Ratio & Spline term on student loan balance to line ratio $>75$ & 3.14 & 3.31 & 3.88 & 4.13 & 4.24 & 4.57 & 4.84 & 4.88 \\
\hline Credit Card Utilization & Spline term on credit card utilization $>75$ & 9.12 & 9.33 & 9.48 & 9.49 & 9.38 & 8.98 & 8.52 & 8.25 \\
\hline Unemployment Rate & Unemployment Rate 6 months lag & 9.21 & 8.52 & 7.87 & 6.85 & 5.84 & 5.15 & 4.84 & 4.25 \\
\hline HELOC Indicator* & Indicator for borrowers with heloc & 0.11 & 0.09 & 0.09 & 0.08 & 0.07 & 0.07 & 0.07 & 0.07 \\
\hline Credit Card Indicator & Indicator for borrowers with credit card & 0.10 & 0.10 & 0.10 & 0.09 & 0.09 & 0.09 & 0.09 & 0.09 \\
\hline Student Loan Indicator & Indicator for borrowers with student loan & 0.84 & 0.83 & 0.81 & 0.81 & 0.81 & 0.81 & 0.81 & 0.82 \\
\hline Auto Loan Count Increase Indicator & $\begin{array}{l}\text { an indicator for whether the new loan adds to any } \\
\text { existing auto loans }\end{array}$ & 0.67 & 0.69 & 0.70 & 0.70 & 0.70 & 0.70 & 0.69 & 0.65 \\
\hline
\end{tabular}

Source: FRBNY Equifax CCP, Haver Analytics, and FFIEC Census file.

Table 4: Long-Term Choice Model for the Cohort with a Mortgage

\begin{tabular}{|c|c|c|c|}
\hline Parameter & Description & Estimate & Std. Error \\
\hline Intercept & & $-1.6067 * * *$ & 0.00993 \\
\hline \multirow[t]{4}{*}{ Equifax Risk Score } & $621-660$ & $0.2541 * * *$ & 0.00528 \\
\hline & $661-720$ & $0.046 * * *$ & 0.00392 \\
\hline & $721-760$ & $-0.2155 * * *$ & 0.00438 \\
\hline & $761+$ & $-0.678 * * *$ & 0.00393 \\
\hline \multirow[t]{7}{*}{ Vintage } & 2011 & $-0.5508 * * *$ & 0.00691 \\
\hline & 2012 & $-0.3555 * * *$ & 0.00615 \\
\hline & 2013 & $-0.2546 * * *$ & 0.00573 \\
\hline & 2014 & $-0.1059 * * *$ & 0.00526 \\
\hline & 2015 & $0.0275 * * *$ & 0.00513 \\
\hline & 2016 & $0.1494 * * *$ & 0.00512 \\
\hline & 2017 & $0.4536 * * *$ & 0.00501 \\
\hline \multirow[t]{3}{*}{ Borrower Age } & $<=35$ & $0.0603 * * *$ & 0.00461 \\
\hline & $35-45$ & $0.0259 * * *$ & 0.00357 \\
\hline & $45-60$ & $-0.0891 * * *$ & 0.00315 \\
\hline HELOC Indicator & No HELOC & $0.0899 * * *$ & 0.00286 \\
\hline \multirow[t]{2}{*}{ MFI } & $<=60000$ & $0.1965 * * *$ & 0.00313 \\
\hline & $60,000-100,000$ & $0.0666 * * *$ & 0.00288 \\
\hline \multirow[t]{3}{*}{ Lender Type } & Auto Finance & $-0.2136 * * *$ & 0.00492 \\
\hline & Banks & $0.0165 * *$ & 0.00517 \\
\hline & Credit Union & $0.3697 * * *$ & 0.00509 \\
\hline \multirow[t]{2}{*}{ Prior Auto Balance } & $<=13000$ & $-0.0756 * * *$ & 0.00295 \\
\hline & $13,000-26,000$ & $-0.2392 * * *$ & 0.00305 \\
\hline \multirow[t]{3}{*}{ Auto High Credit 6 Month Lag } & missing & $-0.0215 * * *$ & 0.0042 \\
\hline & $<15000$ & $-0.0901 * * *$ & 0.00464 \\
\hline & $15,000-28,000$ & $0.0434 * * *$ & 0.00375 \\
\hline Credit Card Indicator & at least one bankcard & $-0.0192 * * *$ & 0.00395 \\
\hline Student Loan Indicator & has student loan & $-0.0334 * * *$ & 0.00354 \\
\hline Auto Loan Count Increase Indicator & no increase in auto loan count & $0.1742 * * *$ & 0.00284 \\
\hline \multirow[t]{2}{*}{ Percent Minority (Tract) } & Minority pop as percent of tract pop $<=10 \%$ & $-0.0614 * * *$ & 0.00314 \\
\hline & Minority pop as percent of tract pop in $10 \%-46 \%$ & $0.0138 * * *$ & 0.0027 \\
\hline Student Loan Balance to Line Ratio & Spline term on student loan balance to hicredit ratio $>75$ & $0.00343 * * *$ & 0.00024 \\
\hline Credit Card Utilization & Spline term on card utilization rate (if $>75$ ) & $0.00757 * * *$ & 0.000211 \\
\hline Unemployment Rate & 6 month lagged unemployment rate & $0.0202 * * *$ & 0.00106 \\
\hline $\mathrm{N}$ & $3,301,340$ & & \\
\hline $\mathrm{AIC}$ & 1767711.2 & & \\
\hline C & 0.699 & & \\
\hline
\end{tabular}


Table 5: Long-Term Choice Model for the Cohort Without a Mortgage

\begin{tabular}{|c|c|c|c|}
\hline Parameter & Description & Estimate & Std. Error \\
\hline Intercept & & $-1.7163 * * *$ & 0.00743 \\
\hline \multirow[t]{4}{*}{ Equifax Risk Score } & $621-660$ & $0.1977 * * *$ & 0.00345 \\
\hline & $661-720$ & $0.0115 * *$ & 0.00319 \\
\hline & $721-760$ & $-0.2051 * * *$ & 0.00454 \\
\hline & $761+$ & $-0.6252 * * *$ & 0.00489 \\
\hline \multirow[t]{7}{*}{ Vintage } & 2011 & $-0.4385 * * *$ & 0.00605 \\
\hline & 2012 & $-0.2507 * * *$ & 0.00515 \\
\hline & 2013 & $-0.1519 * * *$ & 0.00457 \\
\hline & 2014 & $-0.0542 * * *$ & 0.00411 \\
\hline & 2015 & $0.066 * * *$ & 0.00384 \\
\hline & 2016 & $0.132 * * *$ & 0.00384 \\
\hline & 2017 & $0.2913 * * *$ & 0.00387 \\
\hline \multirow[t]{3}{*}{ Borrower Age } & $<=35$ & $-0.1472 * * *$ & 0.00255 \\
\hline & $35-45$ & $0.0414 * * *$ & 0.00287 \\
\hline & $45-60$ & $0.0284 * * *$ & 0.00278 \\
\hline \multirow[t]{2}{*}{ MFI } & $<=60000$ & $0.1277 * * *$ & 0.00256 \\
\hline & $60,000-100,000$ & $0.0499 * * *$ & 0.00255 \\
\hline \multirow[t]{3}{*}{ Lender Type } & Auto Finance & $0.162 * * *$ & 0.00315 \\
\hline & Banks & $0.1226 * * *$ & 0.00385 \\
\hline & Credit Union & $0.3625 * * *$ & 0.00363 \\
\hline \multirow[t]{2}{*}{ Prior Auto Balance } & $<=13000$ & $-0.1751 * * *$ & 0.00224 \\
\hline & $13,000-26,000$ & $-0.1719 * * *$ & 0.00225 \\
\hline \multirow[t]{3}{*}{ Auto High Credit 6 Month Lag } & missing & $-0.1018 * * *$ & 0.00377 \\
\hline & $<15000$ & $-0.0435 * * *$ & 0.00367 \\
\hline & $15,000-28,000$ & $0.0689 * * *$ & 0.00351 \\
\hline Credit Card Indicator & at least one bankcard & $-0.0168 * * *$ & 0.00322 \\
\hline Student Loan Indicator & has student loan & 0.00415 & 0.00293 \\
\hline Auto Loan Count Increase Indicator & no increase in auto loan count & $0.1349 * * *$ & 0.00261 \\
\hline \multirow[t]{2}{*}{ Percent Minority (Tract) } & Minority pop as percent of tract pop $<=10 \%$ & $-0.0862 * * *$ & 0.00275 \\
\hline & Minority pop as percent of tract pop in $10 \%-46 \%$ & $0.0169 * * *$ & 0.00216 \\
\hline Student Loan Balance to Line Ratio & Spline term on student loan balance to hicredit ratio $>75$ & $0.00322 * * *$ & 0.000158 \\
\hline Credit Card Utilization & Spline term on card utilization rate (if $>75$ ) & $0.00871 * * *$ & 0.00015 \\
\hline Unemployment Rate & 6 month lagged unemployment rate & $0.012 * * *$ & 0.000818 \\
\hline $\mathrm{N}$ & $4,042,531$ & & \\
\hline $\mathrm{AIC}$ & 2751241.6 & & \\
\hline C & 0.669 & & \\
\hline
\end{tabular}

Note: Data was based on sample of FRBNY Equifax CCP, Equifax Auto Tradeline data, and Census Tract Data. ${ }^{* * *}$ for $\mathrm{p}<0.01 \%, * *$ for $\mathrm{p}<0.1 \%$, and $*$ for $\mathrm{p}<5 \%$. 
Table 6: Long-Term Choice Model for the Cohort with a Mortgage — Banks Only

\begin{tabular}{|c|c|c|c|}
\hline Parameter & Description & Estimate & Std. Error \\
\hline Intercept & & $-1.5929 * * *$ & 0.0172 \\
\hline \multirow[t]{4}{*}{ Equifax Risk Score } & $621-660$ & $0.2738 * * *$ & 0.0111 \\
\hline & $661-720$ & $0.1287 * * *$ & 0.00749 \\
\hline & $721-760$ & $-0.13 * * *$ & 0.00793 \\
\hline & $761+$ & $-0.615 * * *$ & 0.00743 \\
\hline \multirow[t]{7}{*}{ Vintage } & 2011 & $-0.5936 * * *$ & 0.0128 \\
\hline & 2012 & $-0.3278 * * *$ & 0.0112 \\
\hline & 2013 & $-0.1945 * * *$ & 0.0103 \\
\hline & 2014 & $-0.0736 * * *$ & 0.0098 \\
\hline & 2015 & -0.00957 & 0.00976 \\
\hline & 2016 & $0.0709 * * *$ & 0.00994 \\
\hline & 2017 & $0.479 * * *$ & 0.00949 \\
\hline \multirow[t]{3}{*}{ Borrower Age } & $<=35$ & $0.052 * * *$ & 0.0086 \\
\hline & $35-45$ & 0.00956 & 0.00676 \\
\hline & $45-60$ & $-0.0848 * * *$ & 0.00596 \\
\hline HELOC Indicator & No HELOC & $0.0828 * * *$ & 0.00504 \\
\hline \multirow[t]{2}{*}{$\mathrm{MFI}$} & $<=60000$ & $0.245 * * *$ & 0.00579 \\
\hline & $60,000-100,000$ & $0.06 * * *$ & 0.00534 \\
\hline \multirow[t]{2}{*}{ Prior Auto Balance } & $<=13000$ & $-0.0687 * * *$ & 0.00552 \\
\hline & $13,000-26,000$ & $-0.2248 * * *$ & 0.00584 \\
\hline \multirow[t]{3}{*}{ Auto High Credit 6 Month Lag } & missing & $-0.0188 *$ & 0.00804 \\
\hline & $<15000$ & $-0.0669 * * *$ & 0.00895 \\
\hline & $15,000-28,000$ & $0.0465 * * *$ & 0.00705 \\
\hline Credit Card Indicator & at least one bankcard & $-0.0177 *$ & 0.00695 \\
\hline Student Loan Indicator & has student loan & $-0.0233 * *$ & 0.0065 \\
\hline Auto Loan Count Increase Indicator & no increase in auto loan count & $0.21 * * *$ & 0.0054 \\
\hline \multirow[t]{2}{*}{ Percent Minority (Tract) } & Minority pop as percent of tract pop $<=10 \%$ & $0.034 * * *$ & 0.00562 \\
\hline & Minority pop as percent of tract pop in $10 \%-46 \%$ & $-0.0233 * * *$ & 0.0052 \\
\hline Student Loan Balance to Line Ratio & Spline term on student loan balance to hicredit ratio $>75$ & $0.00381 * * *$ & 0.000502 \\
\hline Credit Card Utilization & Spline term on card utilization rate (if $>75$ ) & $0.00359 * * *$ & 0.000418 \\
\hline Unemployment Rate & 6 month lagged unemployment rate & $0.0182 * * *$ & 0.00203 \\
\hline $\mathrm{N}$ & 981,580 & & \\
\hline $\mathrm{AIC}$ & 496673.29 & & \\
\hline $\mathrm{C}$ & 0.679 & & \\
\hline
\end{tabular}


Table 7: Long-Term Choice Model for the Cohort Without a Mortgage — Banks Only

\begin{tabular}{|c|c|c|c|}
\hline Parameter & Description & Estimate & Std. Error \\
\hline Intercept & & $-1.564 * * *$ & 0.0156 \\
\hline \multirow[t]{4}{*}{ Equifax Risk Score } & $621-660$ & $0.2134 * * *$ & 0.00761 \\
\hline & $661-720$ & $0.0856 * * *$ & 0.00624 \\
\hline & $721-760$ & $-0.1518 * * *$ & 0.00827 \\
\hline & $761+$ & $-0.5848 * * *$ & 0.00928 \\
\hline \multirow[t]{7}{*}{ Vintage } & 2011 & $-0.581 * * *$ & 0.0139 \\
\hline & 2012 & $-0.3051 * * *$ & 0.0115 \\
\hline & 2013 & $-0.1733 * * *$ & 0.0102 \\
\hline & 2014 & $-0.0555 * * *$ & 0.00947 \\
\hline & 2015 & 0.0118 & 0.0091 \\
\hline & 2016 & $0.1009 * * *$ & 0.00909 \\
\hline & 2017 & $0.4216 * * *$ & 0.00884 \\
\hline \multirow[t]{3}{*}{ Borrower Age } & $<=35$ & $-0.1373 * * *$ & 0.00598 \\
\hline & $35-45$ & $0.0136 *$ & 0.00698 \\
\hline & $45-60$ & -0.00277 & 0.00658 \\
\hline \multirow[t]{2}{*}{ MFI } & $<=60000$ & $0.1917 * * *$ & 0.00565 \\
\hline & $60,000-100,000$ & $0.0446 * * *$ & 0.00562 \\
\hline \multirow[t]{2}{*}{ Prior Auto Balance } & $<=13000$ & $-0.1506 * * *$ & 0.0051 \\
\hline & $13,000-26,000$ & $-0.2047 * * *$ & 0.00534 \\
\hline \multirow[t]{3}{*}{ Auto High Credit 6 Month Lag } & missing & $-0.0905 * * *$ & 0.00893 \\
\hline & $<15000$ & $-0.0474 * * *$ & 0.00875 \\
\hline & $15,000-28,000$ & $0.0926 * * *$ & 0.00779 \\
\hline Credit Card Indicator & at least one bankcard & $-0.0209 * * *$ & 0.00637 \\
\hline Student Loan Indicator & has student loan & 0.00502 & 0.00657 \\
\hline Auto Loan Count Increase Indicator & no increase in auto loan count & $0.1842 * * *$ & 0.00615 \\
\hline \multirow[t]{2}{*}{ Percent Minority (Tract) } & Minority pop as percent of tract pop $<=10 \%$ & 0.00971 & 0.00559 \\
\hline & Minority pop as percent of tract pop in $10 \%-46 \%$ & $-0.0312 * * *$ & 0.00488 \\
\hline Student Loan Balance to Line Ratio & Spline term on student loan balance to hicredit ratio $>75$ & $0.00326 * * *$ & 0.000415 \\
\hline Credit Card Utilization & Spline term on card utilization rate (if $>75$ ) & $0.00378 * * *$ & 0.000351 \\
\hline Unemployment Rate & 6 month lagged unemployment rate & $0.0129 * * *$ & 0.0019 \\
\hline $\mathrm{N}$ & 869,814 & & \\
\hline $\mathrm{AIC}$ & 528589.56 & & \\
\hline $\mathrm{C}$ & 0.664 & & \\
\hline
\end{tabular}

Note: Data was based on sample of FRBNY Equifax CCP, Equifax Auto Tradeline data, and Census Tract Data. ${ }^{* * *}$ for $\mathrm{p}<0.01 \%, * *$ for $\mathrm{p}<0.1 \%$, and $*$ for $\mathrm{p}<5 \%$. 
Table 8: Variable Definitions and Sample Mean Values for the Default Model

\begin{tabular}{|c|c|c|c|c|c|c|c|}
\hline Variable & Label & 2011 & 2012 & 2013 & 2014 & 2015 & 2016 \\
\hline Equifax Risk Score & Equifax risk score & 693 & 688 & 686 & 685 & 682 & 684 \\
\hline Borrower Age & Borrower age & 47 & 47 & 48 & 47 & 47 & 46 \\
\hline MFI & Median family income at tract level & 70819 & 70129 & 69775 & 69182 & 68297 & 67958 \\
\hline Auto Loan Amount & Current auto loan amount & 22297 & 22683 & 23049 & 23567 & 24144 & 24560 \\
\hline First Mortgage Payment & First mortgage payment & 1522 & 1487 & 1466 & 1479 & 1481 & 1512 \\
\hline Term & Auto loan term & 67 & 67 & 68 & 69 & 69 & 70 \\
\hline Auto Payment to Income Ratio & Auto monthly parment to income ratio & 7.78 & 7.89 & 7.99 & 8.13 & 8.37 & 8.46 \\
\hline Percent Minority (Tract) & Percentage Minority at tract level & 30.49 & 31.43 & 32.17 & 32.79 & 33.63 & 34.00 \\
\hline Credit Card Utilization & Spline term on credit card utilization $>75$ & 9.12 & 9.33 & 9.48 & 9.49 & 9.38 & 8.98 \\
\hline Unemployment Rate & Unemployment Rate 6 months lag & 9.21 & 8.52 & 7.87 & 6.85 & 5.84 & 5.15 \\
\hline HELOC Indicator & Indicator for borrowers with heloc & 0.11 & 0.09 & 0.09 & 0.08 & 0.07 & 0.07 \\
\hline Joint Account & Indicator for borrowers with joint account & 0.51 & 0.50 & 0.49 & 0.49 & 0.48 & 0.48 \\
\hline Student Loan Indicator & Indicator for borrowers with student loan & 0.84 & 0.83 & 0.81 & 0.81 & 0.81 & 0.81 \\
\hline Credit Card Indicator & Indicator for borrowers with credit card & 0.10 & 0.10 & 0.10 & 0.09 & 0.09 & 0.09 \\
\hline Auto Loan Count Increase Indicator & $\begin{array}{l}\text { Indicator for whether the new loan adds to any } \\
\text { existing auto loans }\end{array}$ & 0.67 & 0.69 & 0.70 & 0.70 & 0.70 & 0.70 \\
\hline
\end{tabular}

Source: FRBNY Equifax CCP, Haver Analytics, and FFIEC Census file. 


\section{Table 9: Default Model for Cohort with a Mortgage}

\begin{tabular}{|c|c|c|c|}
\hline Parameter & Description & Estimate & Std. Error \\
\hline Intercept & & $-4.9875 * * *$ & 0.0366 \\
\hline \multirow[t]{4}{*}{ Equifax Risk Score } & $621-660$ & $0.7774 * * *$ & 0.0187 \\
\hline & $661-720$ & $0.1344 * * *$ & 0.0182 \\
\hline & $721-760$ & $-0.6976 * * *$ & 0.0265 \\
\hline & $761+$ & $-2.0436 * * *$ & 0.0329 \\
\hline \multirow[t]{5}{*}{ Vintage } & 2011 & $0.0345 *$ & 0.0175 \\
\hline & 2012 & $-0.0333^{*}$ & 0.0164 \\
\hline & 2013 & $-0.0915 * * *$ & 0.0164 \\
\hline & 2014 & $-0.135 * * *$ & 0.0167 \\
\hline & 2015 & $0.0795 * * *$ & 0.0163 \\
\hline \multirow[t]{3}{*}{ Borrower Age } & $<=35$ & $0.2743 * * *$ & 0.015 \\
\hline & $35-45$ & $-0.0578 * * *$ & 0.0125 \\
\hline & $45-60$ & $-0.1947 * * *$ & 0.0112 \\
\hline \multirow[t]{2}{*}{ MFI } & $<=60000$ & 0.00394 & 0.0121 \\
\hline & $60,000-100,000$ & $0.2048 * * *$ & 0.015 \\
\hline \multirow[t]{3}{*}{ Lender Type } & Auto Finance & 0.0228 & 0.0133 \\
\hline & Banks & $0.12 * * *$ & 0.0128 \\
\hline & Credit Union & $-0.2127 * * *$ & 0.0173 \\
\hline HELOC Indicator & Don't have HELOC & $-0.307 * * *$ & 0.0174 \\
\hline \multirow[t]{2}{*}{ Auto High Credit } & $<15000$ & $0.1381 * * *$ & 0.0152 \\
\hline & $15,000-28,000$ & $0.0263 * *$ & 0.00986 \\
\hline Joint Account & Single borrower & $0.1301 * * *$ & 0.00724 \\
\hline \multirow[t]{2}{*}{ First Mortgage Payment } & $<=1000$ & $0.1369 * * *$ & 0.0106 \\
\hline & $1,000-1,300$ & $-0.0795 * * *$ & 0.0123 \\
\hline \multirow[t]{2}{*}{ Term } & $5 y r$ & $-0.1155 * * *$ & 0.0121 \\
\hline & $6 y r$ & $-0.1781 * * *$ & 0.00984 \\
\hline Student Loan Indicator & has student loan & $-0.1874 * * *$ & 0.0101 \\
\hline Credit Card Indicator & at least one bankcard & $-0.0537 *$ & 0.0211 \\
\hline \multirow[t]{2}{*}{ Auto Payment to Income Ratio } & $<0.4$ & $-0.0471 * *$ & 0.0149 \\
\hline & $0.40-1.00$ & $-0.0813 * * *$ & 0.0101 \\
\hline Auto Loan Count Increase Indicator & no increase in auto loan count & $0.0436 * * *$ & 0.00788 \\
\hline \multirow[t]{2}{*}{ Percent Minority (Tract) } & Minority pop as percent of tract pop $<=10 \%$ & $-0.0842 * * *$ & 0.012 \\
\hline & Minority pop as percent of tract pop in $10 \%-46 \%$ & $0.044 * * *$ & 0.00986 \\
\hline Credit Card Utilization & spline term on card utilization rate (if $>75$ ) & $0.0166 * * *$ & 0.000695 \\
\hline Unemployment Rate & 6 month lagged unemployment rate & $0.0277^{* * *}$ & 0.00327 \\
\hline $\mathrm{N}$ & $2,663,655$ & & \\
\hline $\mathrm{AIC}$ & 223477.38 & & \\
\hline $\mathrm{C}$ & 0.878 & & \\
\hline
\end{tabular}

Note: Data was based on sample of FRBNY Equifax CCP, Equifax Auto Tradeline data, and Census Tract Data. ${ }^{* * *}$ for $\mathrm{p}<0.01 \%$, ${ }^{* *}$ for $\mathrm{p}<0.1 \%$, and $*$ for $\mathrm{p}<5 \%$. 
Table 10: Default Model for Cohort Without a Mortgage

\begin{tabular}{|c|c|c|c|}
\hline Parameter & Description & Estimate & Std. Error \\
\hline Intercept & & $-4.6265 * * *$ & 0.0174 \\
\hline \multirow[t]{4}{*}{ Equifax Risk Score } & $621-660$ & $0.735 * * *$ & 0.0122 \\
\hline & $661-720$ & -0.0175 & 0.0136 \\
\hline & $721-760$ & $-0.8569 * * *$ & 0.0241 \\
\hline & $761+$ & $-1.6828 * * *$ & 0.0321 \\
\hline \multirow[t]{5}{*}{ Vintage } & 2011 & $-0.1723 * * *$ & 0.0096 \\
\hline & 2012 & $-0.1256 * * *$ & 0.00826 \\
\hline & 2013 & $-0.0493 * * *$ & 0.00736 \\
\hline & 2014 & $-0.0758 * * *$ & 0.00701 \\
\hline & 2015 & $0.1752 * * *$ & 0.00656 \\
\hline \multirow[t]{3}{*}{ Borrower Age } & $<=35$ & $0.2839 * * *$ & 0.00494 \\
\hline & $35-45$ & $-0.0576 * * *$ & 0.00587 \\
\hline & $45-60$ & $-0.1839 * * *$ & 0.006 \\
\hline \multirow[t]{2}{*}{ MFI } & $<=60000$ & $0.2851 * * *$ & 0.00681 \\
\hline & $60,000-100,000$ & $-0.0152 *$ & 0.00665 \\
\hline \multirow[t]{3}{*}{ Lender Type } & Auto Finance & $0.2019 * * *$ & 0.00524 \\
\hline & Banks & $-0.3781 * * *$ & 0.00865 \\
\hline & Credit Union & $-0.3181 * * *$ & 0.00769 \\
\hline \multirow[t]{2}{*}{ Auto High Credit } & $<15000$ & $0.036 * * *$ & 0.00599 \\
\hline & $15,000-28,000$ & $0.0673 * * *$ & 0.0045 \\
\hline Joint Account & Single borrower & $0.1992 * * *$ & 0.00319 \\
\hline \multirow[t]{2}{*}{ Term } & $5 y r$ & $0.2149 * * *$ & 0.00477 \\
\hline & $6 y r$ & $-0.2444 * * *$ & 0.00427 \\
\hline Student Loan Indicator & has student loan & $-0.1592 * * *$ & 0.00377 \\
\hline Credit Card Indicator & at least one bankcard & $-0.2645 * * *$ & 0.00786 \\
\hline \multirow[t]{2}{*}{ Auto Payment to Income Ratio } & $<0.4$ & $-0.1194 * * *$ & 0.00614 \\
\hline & $0.40-1.00$ & $-0.0985 * * *$ & 0.00442 \\
\hline Auto Loan Count Increase Indicator & no increase in auto loan count & $-0.073 * * *$ & 0.00407 \\
\hline \multirow[t]{2}{*}{ Percent Minority (Tract) } & Minority pop as percent of tract pop $<=10 \%$ & $-0.0547 * * *$ & 0.00603 \\
\hline & Minority pop as percent of tract pop in $10 \%-46 \%$ & $0.0293 * * *$ & 0.00457 \\
\hline Credit Card Utilization & spline term on card utilization rate (if $>75$ ) & $0.0314 * * *$ & 0.000336 \\
\hline Unemployment Rate & 6 month lagged unemployment rate & $0.00693 * * *$ & 0.0015 \\
\hline $\mathrm{N}$ & $3,214,567$ & & \\
\hline $\mathrm{AIC}$ & 944953.58 & & \\
\hline C & 0.823 & & \\
\hline
\end{tabular}


Table 11: Default Model for Cohort with a Mortgage — Banks Only

\begin{tabular}{|c|c|c|c|}
\hline Parameter & Description & Estimate & Std. Error \\
\hline Intercept & & $-5.2435 * * *$ & 0.085 \\
\hline \multirow{4}{*}{ Equifax Risk Score } & $621-660$ & $0.7935 * * *$ & 0.0405 \\
\hline & $661-720$ & $0.0931 *$ & 0.035 \\
\hline & $721-760$ & $-0.6897 * * *$ & 0.0474 \\
\hline & $761+$ & $-1.9606 * * *$ & 0.0605 \\
\hline \multirow[t]{5}{*}{ Vintage } & 2011 & $0.1388 *$ & 0.0437 \\
\hline & 2012 & 0.0719 & 0.041 \\
\hline & 2013 & $-0.1738 * * *$ & 0.0428 \\
\hline & 2014 & $-0.2739 * * *$ & 0.0454 \\
\hline & 2015 & 0.0709 & 0.0425 \\
\hline \multirow[t]{3}{*}{ Borrower Age } & $<=35$ & $0.1118 *$ & 0.0383 \\
\hline & $35-45$ & $-0.1398 * * *$ & 0.0336 \\
\hline & $45-60$ & $-0.1709 * * *$ & 0.0294 \\
\hline \multirow[t]{2}{*}{ MFI } & $<=60000$ & 0.00928 & 0.0274 \\
\hline & $60,000-100,000$ & $0.2465 * * *$ & 0.0374 \\
\hline HELOC Indicator & Don't have HELOC & $0.0627 * * *$ & 0.0331 \\
\hline \multirow[t]{2}{*}{ Auto High Credit } & $<15000$ & $0.3072 * * *$ & 0.0408 \\
\hline & $15,000-28,000$ & $-0.0813 *$ & 0.026 \\
\hline Joint Account & Single borrower & $0.2621 * * *$ & 0.0193 \\
\hline \multirow[t]{2}{*}{ First Mortgage Payment } & $<=1000$ & $0.1274 * * *$ & 0.0272 \\
\hline & $1,000-1,300$ & $-0.108 * *$ & 0.0317 \\
\hline \multirow[t]{2}{*}{ Term } & $5 y r$ & $-0.4861 * * *$ & 0.0332 \\
\hline & $6 y r$ & $-0.1145 * * *$ & 0.0254 \\
\hline Student Loan Indicator & has student loan & $-0.1897 * * *$ & 0.0267 \\
\hline Credit Card Indicator & at least one bankcard & -0.0369 & 0.0435 \\
\hline \multirow[t]{2}{*}{ Auto Payment to Income Ratio } & $<0.4$ & -0.0367 & 0.0372 \\
\hline & $0.40-1.00$ & $-0.0793 *$ & 0.0259 \\
\hline Auto Loan Count Increase Indicator & no increase in auto loan count & $0.0604 *$ & 0.0197 \\
\hline \multirow[t]{2}{*}{ Percent Minority (Tract) } & Minority pop as percent of tract pop $<=10 \%$ & $-0.137 * * *$ & 0.0287 \\
\hline & Minority pop as percent of tract pop in $10 \%-46 \%$ & 0.0292 & 0.0252 \\
\hline Credit Card Utilization & spline term on card utilization rate (if $>75$ ) & $0.0112 * * *$ & 0.00172 \\
\hline Unemployment Rate & 6 month lagged unemployment rate & $0.0341 * * *$ & 0.00846 \\
\hline $\mathrm{N}$ & 803,277 & & \\
\hline $\mathrm{AIC}$ & 37335.44 & & \\
\hline $\mathrm{C}$ & 0.868 & & \\
\hline
\end{tabular}

Note: Data was based on sample of FRBNY Equifax CCP, Equifax Auto Tradeline data, and Census Tract Data. ${ }^{* * *}$ for $\mathrm{p}<0.01 \%,{ }^{* *}$ for $\mathrm{p}<0.1 \%$, and $*$ for $\mathrm{p}<5 \%$. 
Table 12: Default Model for Cohort Without a Mortgage — Banks Only

\begin{tabular}{|c|c|c|c|}
\hline Parameter & Description & Estimate & Std. Error \\
\hline Intercept & & $-4.9776 * * *$ & 0.0484 \\
\hline \multirow[t]{4}{*}{ Equifax Risk Score } & $621-660$ & $0.5924 * * *$ & 0.0273 \\
\hline & $661-720$ & $-0.122 * * *$ & 0.0282 \\
\hline & $721-760$ & $-0.7422 * * *$ & 0.0444 \\
\hline & $761+$ & $-1.4789 * * *$ & 0.0582 \\
\hline \multirow[t]{5}{*}{ Vintage } & 2011 & $-0.1583 * * *$ & 0.0309 \\
\hline & 2012 & $-0.0879 * *$ & 0.0265 \\
\hline & 2013 & $-0.0881 * *$ & 0.0246 \\
\hline & 2014 & $-0.1766 * * *$ & 0.0247 \\
\hline & 2015 & $0.1784 * * *$ & 0.0224 \\
\hline \multirow[t]{3}{*}{ Borrower Age } & $<=35$ & $0.0654 * * *$ & 0.0165 \\
\hline & $35-45$ & $-0.1669 * * *$ & 0.0205 \\
\hline & $45-60$ & $-0.1561 * * *$ & 0.02 \\
\hline \multirow[t]{2}{*}{ MFI } & $<=60000$ & $0.3121 * * *$ & 0.0215 \\
\hline & $60,000-100,000$ & -0.04 & 0.0209 \\
\hline \multirow[t]{2}{*}{ Auto High Credit } & $<15000$ & $0.1553 * * *$ & 0.0207 \\
\hline & $15,000-28,000$ & -0.0112 & 0.0143 \\
\hline Joint Account & Single borrower & $0.394 * * *$ & 0.0115 \\
\hline \multirow[t]{2}{*}{ Term } & $5 y r$ & $-0.2287 * * *$ & 0.0174 \\
\hline & $6 y r$ & $-0.2186 * * *$ & 0.0142 \\
\hline Student Loan Indicator & has student loan & $-0.212 * * *$ & 0.0137 \\
\hline Credit Card Indicator & at least one bankcard & $-0.1617 * * *$ & 0.0222 \\
\hline \multirow[t]{2}{*}{ Auto Payment to Income Ratio } & $<0.4$ & $-0.0973 * * *$ & 0.0203 \\
\hline & $0.40-1.00$ & $-0.0917 * * *$ & 0.0147 \\
\hline Auto Loan Count Increase Indicator & no increase in auto loan count & $-0.0434 * *$ & 0.0127 \\
\hline \multirow[t]{2}{*}{ Percent Minority (Tract) } & Minority pop as percent of tract pop $<=10 \%$ & $-0.1345 * * *$ & 0.0182 \\
\hline & Minority pop as percent of tract pop in $10 \%-46 \%$ & 0.0171 & 0.0149 \\
\hline Credit Card Utilization & spline term on card utilization rate (if $>75$ ) & $0.0265 * * *$ & 0.00101 \\
\hline Unemployment Rate & 6 month lagged unemployment rate & $0.0149 * * *$ & 0.0049 \\
\hline $\mathrm{N}$ & 695,325 & & \\
\hline $\mathrm{AIC}$ & 96758.01 & & \\
\hline $\mathrm{C}$ & 0.839 & & \\
\hline
\end{tabular}




\section{Appendix 1: Imputation of Loan Term}

In the Equifax Auto Tradeline data, only 9 percent of the loans have the term-to-maturity term populated. To impute a term-to-maturity, we first had to impute an interest rate. In most cases, we were able to impute the interest rate on the loan using recorded information on required monthly payment and the change in principal balance across observation dates.

Change in the principal balance may vary across the six-month observation intervals in the data because of borrowers making more than the required monthly payment in some months. Therefore, for each loan, we used the median observed change in principal balance for inferring the interest rate, subject to two restrictions:

1. The first balance observation date must be at least four months after the date of origination, and

2. The loan has had no payment delinquency within the 12 months prior to, or during, the observed six-month balance change interval.

Once the interest rate is determined, the term-to-maturity can be calculated using the standard amortization formula, given the required monthly payment. Using this procedure, we were able to impute term-to-maturity for about 78 percent of the loans in the sample.

For some loans, primarily because of short or sporadic balance history, this method could not be reliably applied. In these cases, we applied a regression-based imputation approach where feasible. The regression equation was estimated using the ( 9 percent) subsample for which term-to-maturity is known. It predicts the ratio between the loan's termto-maturity, and a baseline term-to-maturity that is calculated given the loan's required monthly payment and an interest rate equal to the prime rate as of the loan's origination date. Covariates include Risk Score at origination, lender type, loan amount, origination vintage, and county unemployment rate as of the date of origination.

Here is summary of the term imputation waterfall:

1. If term-to-maturity is reported at any of the panel observation dates, then it is known (9 percent).

2. If not, we impute the interest rate and then calculate the term-to-maturity based on required monthly payment and observed balance change series (78 percent).

3. If the data do not support reliable imputation of the interest rate, we apply the regression-based imputation model (12 percent).

4. If the regression model could not be applied because of missing data, the observation was dropped from the sample (1 percent). 


\section{Appendix 2: Supplementary Charts}

\section{Figure A-1: Long-Term Choice Model ROC Curve}

\section{ROC Curve for Model}

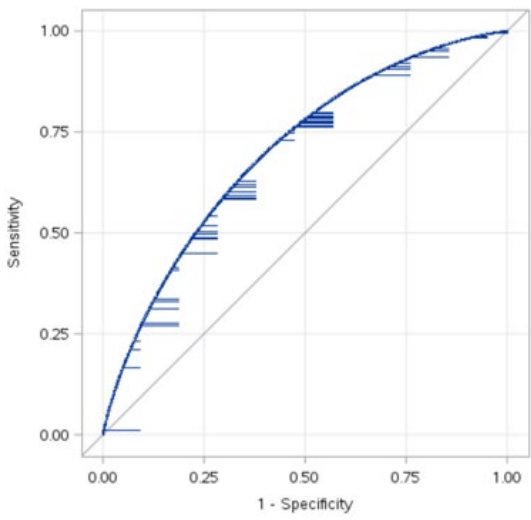

Source: FRBNY Equifax CCP. Sample restricted to loans with term-to-maturity $>48$ months.

Note: The Area Under the Curve (AUC) is a conventional performance metric for a ROC curve. ROC curve plots the true positive rate (TPR) against the false positive rate (FPR) at variouos thresholds of the predicted probability. The higher the area under the curve, the better prediction power the model has; $c=0.68$ implies that a randomly selected individual from the positive group has a test value larger than that for a randomly chosen individual from the negative group 68 percent of the time.

\section{Figure A-2: Default Model ROC Curve}

\section{ROC Curve for Model}

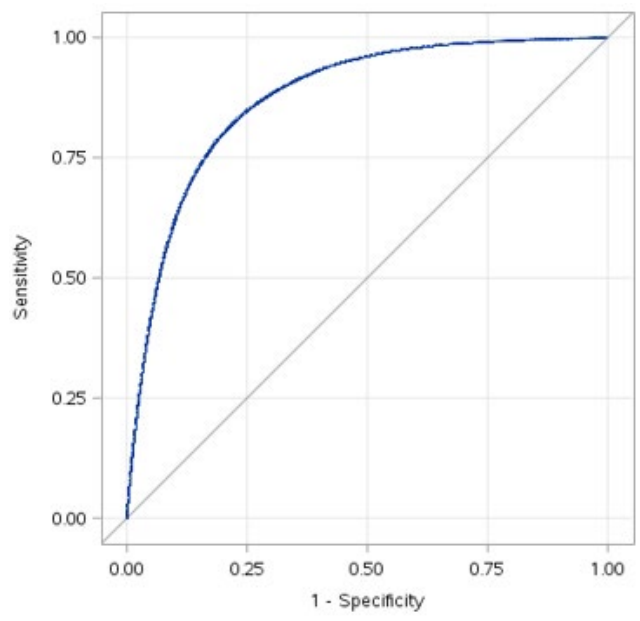

Source: FRBNY Equifax CCP. Sample restricted to loans with term-to-maturity $>48$ months. 


\section{Appendix 3: Default Model Alternative Specification}

\section{Table 13: Default Model for the Cohort with a Mortgage}

\begin{tabular}{|c|c|c|c|}
\hline Parameter & Description & Estimate & Std. Error \\
\hline Intercept & & $-5.333 * * *$ & 0.0384 \\
\hline \multirow[t]{4}{*}{ Equifax Risk Score } & $621-660$ & $0.73 * * *$ & 0.0191 \\
\hline & $661-720$ & $0.1934 * * *$ & 0.0186 \\
\hline & $721-760$ & $-0.589 * * *$ & 0.0273 \\
\hline & $761+$ & $-1.9031 * * *$ & 0.0341 \\
\hline \multirow[t]{5}{*}{ Vintage } & 2011 & $-0.00623 *$ & 0.0178 \\
\hline & 2012 & $-0.0868 *$ & 0.0167 \\
\hline & 2013 & $-0.1001 * * *$ & 0.0166 \\
\hline & 2014 & $-0.0994 * * *$ & 0.0169 \\
\hline & 2015 & $0.116 * * *$ & 0.0166 \\
\hline \multirow[t]{3}{*}{ Borrower Age } & $<=35$ & $0.2848 * * *$ & 0.0152 \\
\hline & $35-45$ & $-0.0672 * * *$ & 0.0127 \\
\hline & $45-60$ & $-0.2067 * * *$ & 0.0114 \\
\hline \multirow[t]{2}{*}{ MFI } & $<=60000$ & -0.0211 & 0.0124 \\
\hline & $60,000-100,000$ & $0.2472 * * *$ & 0.0151 \\
\hline \multirow[t]{3}{*}{ Lender Type } & Auto Finance & 0.0249 & 0.0135 \\
\hline & Banks & $0.1159 * * *$ & 0.0131 \\
\hline & Credit Union & $-0.0968 * * *$ & 0.0179 \\
\hline HELOC Indicator & Don't have HELOC & $-0.178 * * *$ & 0.0179 \\
\hline \multirow[t]{2}{*}{ Auto High Credit } & $<15000$ & $-0.1308 * * *$ & 0.0166 \\
\hline & $15,000-28,000$ & $0.0448 * *$ & 0.01 \\
\hline Joint Account & Single borrower & $0.1218 * * *$ & 0.00734 \\
\hline \multirow[t]{2}{*}{ First Mortgage Payment } & $<=1000$ & $0.126 * * *$ & 0.0107 \\
\hline & $1,000-1,300$ & $-0.0736 * * *$ & 0.0125 \\
\hline \multirow[t]{2}{*}{ Term } & $5 y r$ & $-0.0215 * * *$ & 0.0125 \\
\hline & $6 y r$ & $-0.1407 * * *$ & 0.0101 \\
\hline Student Loan Indicator & has student loan & $-0.1816 * * *$ & 0.0102 \\
\hline Credit Card Indicator & at least one bankcard & $-0.049 *$ & 0.0214 \\
\hline \multirow[t]{2}{*}{ Auto Payment to Income Ratio } & $<0.4$ & $0.0783 * *$ & 0.0151 \\
\hline & $0.40-1.00$ & $-0.0735 * * *$ & 0.0103 \\
\hline Auto Loan Count Increase Indicator & no increase in auto loan count & $0.0579 * * *$ & 0.00801 \\
\hline \multirow[t]{2}{*}{ Percent Minority (Tract) } & Minority pop as percent of tract pop $<=10 \%$ & $-0.056 * * *$ & 0.0121 \\
\hline & Minority pop as percent of tract pop in $10 \%-46 \%$ & $0.036 * * *$ & 0.01 \\
\hline Spread Origination & Interest rate spread origination & 0.0632 & 0.00145 \\
\hline Credit Card Utilization & spline term on card utilization rate (if $>75$ ) & $0.0109 * * *$ & 0.000723 \\
\hline Unemployment Rate & 6 month lagged unemployment rate & $0.0287^{* * *}$ & 0.00333 \\
\hline $\mathrm{N}$ & $2,456,927$ & & \\
\hline $\mathrm{AIC}$ & 216346.11 & & \\
\hline $\mathrm{C}$ & 0.879 & & \\
\hline
\end{tabular}


Table 14: Default Model for the Cohort Without a Mortgage

\begin{tabular}{|c|c|c|c|}
\hline Parameter & Description & Estimate & Std. Error \\
\hline Intercept & & $-4.9658 * * *$ & 0.0181 \\
\hline \multirow[t]{4}{*}{ Equifax Risk Score } & $621-660$ & $0.6347 * * *$ & 0.0125 \\
\hline & $661-720$ & $0.0298 *$ & 0.0138 \\
\hline & $721-760$ & $-0.6937 * * *$ & 0.0246 \\
\hline & $761+$ & $-1.4794 * * *$ & 0.033 \\
\hline \multirow[t]{5}{*}{ Vintage } & 2011 & $-0.1802 * * *$ & 0.00973 \\
\hline & 2012 & $-0.1688 * * *$ & 0.00839 \\
\hline & 2013 & $-0.0557 * * *$ & 0.00746 \\
\hline & 2014 & $-0.0482 * * *$ & 0.00711 \\
\hline & 2015 & $0.1937 * * *$ & 0.00666 \\
\hline \multirow[t]{3}{*}{ Borrower Age } & $<=35$ & $0.295 * * *$ & 0.00501 \\
\hline & $35-45$ & $-0.0842 * * *$ & 0.00595 \\
\hline & $45-60$ & $-0.1998 * * *$ & 0.00608 \\
\hline \multirow[t]{2}{*}{ MFI } & $<=60000$ & $0.3219 * * *$ & 0.00685 \\
\hline & $60,000-100,000$ & $-0.021 *$ & 0.00675 \\
\hline \multirow[t]{3}{*}{ Lender Type } & Auto Finance & $0.1436 * * *$ & 0.00537 \\
\hline & Banks & $-0.2255 * * *$ & 0.0089 \\
\hline & Credit Union & $-0.1391 * * *$ & 0.00794 \\
\hline \multirow[t]{2}{*}{ Auto High Credit } & $<15000$ & $-0.3018 * * *$ & 0.00673 \\
\hline & $15,000-28,000$ & $0.0832 * * *$ & 0.00457 \\
\hline Joint Account & Single borrower & $0.1626 * * *$ & 0.00324 \\
\hline \multirow[t]{2}{*}{ Term } & $5 y r$ & $0.3288 * * *$ & 0.00495 \\
\hline & $6 y r$ & $-0.1996 * * *$ & 0.00436 \\
\hline Student Loan Indicator & has student loan & $-0.1446 * * *$ & 0.00383 \\
\hline Credit Card Indicator & at least one bankcard & $-0.2182 * * *$ & 0.00801 \\
\hline \multirow[t]{2}{*}{ Auto Payment to Income Ratio } & $<0.4$ & $0.0268 * * *$ & 0.00628 \\
\hline & $0.40-1.00$ & $-0.0889 * * *$ & 0.00451 \\
\hline Auto Loan Count Increase Indicator & no increase in auto loan count & $-0.0447 * * *$ & 0.00413 \\
\hline \multirow[t]{2}{*}{ Percent Minority (Tract) } & minority pop as percent of tract pop $<=10 \%$ & $-0.0196 *$ & 0.00612 \\
\hline & minority pop as percent of tract pop in $10 \%-46 \%$ & 0.00872 & 0.00464 \\
\hline Spread Origination & Interest rate spread origination & $0.0624 * * *$ & 0.000552 \\
\hline Credit Card Utilization & spline term on card utilization rate (if $>75$ ) & $0.0248 * * *$ & 0.000348 \\
\hline Unemployment Rate & 6 month lagged unemployment rate & $0.00636 * * *$ & 0.00152 \\
\hline $\mathrm{N}$ & $3,050,405$ & & \\
\hline $\mathrm{AIC}$ & 923317.55 & & \\
\hline $\mathrm{C}$ & 0.83 & & \\
\hline
\end{tabular}




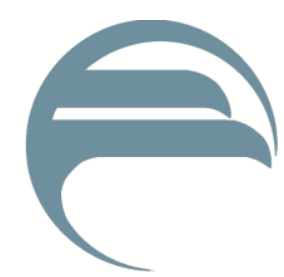

FEDERAL Reserve BANK of PHILADELPHiA

Consumer Finance Institute Discussion Paper Series

http://www.philadelphiafed.org/consumer-finance-institute 